Népegészségügy - Eredeti közlemény / Public health - Original article

Bényi Mária, Kéki Zsuzsanna, Muzsik Béla, Körösi László

Országos Kórházi Főigazgatóság, Budapest / National Hospital Directorate General, Budapest, Hungary

DOI: https://doi.org/10.29179/EgTud.2021.1.19-38

\title{
Krónikus betegségek alakulása felnött lakosság körében az OSAP 1021 háziorvosi jelentések alapján 1999-2019. években Magyarországon
}

Development of chronic diseases among the adult population based on OSAP 1021 GP reports 1999-2019. years in Hungary

\begin{abstract}
Összefoglalás
Az OSAP 1021 háziorvosi statisztikai jelentés alapján 1999. óta nyomon követhető több mint 30 krónikus betegség alakulása Magyarországon.

A jelentésben szereplő adatok 35 betegségre vonatkozóan a KSH honlapjáról kerültek lekérdezésre. Az adatok alakulását vizsgáltuk a kezdőévhez viszonyítva, továbbá 1000 före nemenként és 3 korcsoportban (19-34 év, 35-64 év, 65 év és több).

A betegségek száma átlagosan kétszeres mértékben nőtt 21 év alatt. A növekedés mértékét illetően kiugróan magas arányban fordultak elő pajzsmirigy elváltozások. Nem nőtt a vizsgált időszakban fiatalkori izületi gyulladás, az emésztőszervi fekélyek, továbbá a vakság és gyengénlátás.

Legnagyobb számban a magas vérnyomás (3,16 millió), spondylopathiák (2,17 millió), lipoprotein-anyagcserezavar (1,39 millió), ischaemiás szívbetegség (1,17 millió) és a diabetes mellitus (1,09 millió) jelenik meg. A betegségszám növekedést a kórházi beavatkozásokkal, laboratóriumi vizsgálatok számával, a gyógyszerfogyasztással, az idősödéssel és a lehetséges környezeti tényezőkkel próbáltuk magyarázni. Javaslatot tettünk a jelentés tartalmának és felhasználás módjának megváltoztatására.
\end{abstract}

Kulcsszavak: morbiditás, felnőtt, házorvosi jelentés, KSH

\begin{abstract}
Based on the OSAP 1021 general practitioner statistical report, the development of more than 30 chronic diseases in Hungary since 1999 can be followed.

The data in the report were queried from the CSO's website for 35 diseases. We examined the development of the data compared to the initial year, as well as per 7000 persons by sex and in 3 age groups (19-34 years, 35-64 years, 65 years and more). The number of diseases has doubled on average in 21 years. In terms of the rate of growth, thyroid lesions are remarkably high. There was no increase in juvenile arthritis, gastrointestinal ulcers, and blindness and low vision during the study period.

The highest numbers appear in hypertension (3.16 million), spondylopathies (2.17 million), lipoprotein metabolism disorders (1.39 million), ischemic heart disease (1.17 million) and diabetes mellitus (1.09 million). We tried to explain the increase in the number of diseases by hospital interventions, the number of laboratory tests, drug use, aging, and possible environmental factors. We have proposed changes to the content and use of this report.
\end{abstract}

Keywords: morbidity, adult, GP report, CSO 


\section{EGÉSZSÉGTUDOMÁNY}

2021;65(2): 19-38

HEALTH SCIENCE

Közlésre érkezett: 2027. január 10.

Submitted: 10 January 2027

Elfogadva: 2021. március 3.

Accepted: 3 March 2021

Levelezési cím/Correspondence:

Dr. Bényi Mária

E-mail: benyi.maria@gmail.com

\section{Bevezetés}

A magyar lakosság halálozási mutatói széles körben ismertek, nemzetközi összehasonlításban is elég kedvezótlenek'. Sokkal kevesebbet tudunk a morbiditási adatokról. A lakossági egészségfelmérésekből kirajzolódik egy kép a betegségekre vonatkozóan, melyek reprezentatív mintán, és általában önbevalláson alapulnak². A Háziorvosi Morbiditási Adatgyűjtési Program (HMAP) keretében 1998-tól folyt több megyében adatgyújtés, melyet a Debreceni Egyetem koordinált³. Az Országos Egészségbiztosítási Pénztár (jelenleg: Nemzeti Egészségbiztosítási Alapkezelő, a továbbiakban: NEAK) által kezelt adatokból is készült már öszszefoglaló, melyből számszerüen láthatóak az összes háziorvosnál különböző betegséggel megjelent páciensek ${ }^{4}$. A háziorvosi, házi gyermekorvosi betegforgalomról a KSH web-es felületén találhatunk adatokat ${ }^{5}$.

1999. évtől létezik az Országos Statisztikai Adatfelvételi Programon (OSAP) belül egy adatgyűjtés (száma: OSAP 1021), amelyből a háziorvosi gondozásban megjelenő krónikus betegségekről kaphatunk képet, kétéves gyakorisággal'. Meg kell jegyezni, hogy a háziorvosok a betegségek számát jelentik, azaz, ha egy beteg több betegségben szenved, akkor betegségei külön-külön kerülnek jelentésre.

Mivel az adatszolgáltatás, kevés változtatással, hoszszú ideje múködik, lehetőséget teremt arra, hogy a krónikus betegségek trendjét megvizsgáljuk.

\section{Adatok, módszer}

Az OSAP 1021 keretében szolgáltatott adatok a KSH honlapján megtalálhatók, és leválogathatók az 19992019. közötti időszakra vonatkozóan. A bejelentésben szereplő összes betegséget az 1. ábrán soroltuk fel. Két fertőző betegség (TBC, vírusos májgyulladás) jelentése időközben megszúnt, ezeket nem számoltuk. 2009. évtől a jelentendő betegségek köre öt betegséggel bővült. Így az alkoholos májbetegség és alkohol okozta mentális viselkedési zavarok, továbbá a Parkinson-kór, zöldhályog és a szemlencse betegségei változását az elmúlt 11 évre vonatkozóan mutatjuk be.

A rendelkezésre álló adatsor alapján vizsgáljuk a betegséggyakoriság növekedésének mértékét az elmúlt 21 év alatt. Betegségcsoportonként ismertetésre kerül a betegségek 1000 felnőttre vonatkozó aránya, kétéves gyakorisággal. Egyes betegségeknél nemenként és 3 korcsoportra (19-34-, 35-64-, 65-X év) is bemutatásra kerülnek az adatok, ugyancsak 1000 före vetítve.

\section{Eredimények}

A háziorvosok által jelentett 35 betegséggel küzdők száma növekedésének mértékét (2019/1999. évi adat) az 1. ábrán mutatjuk be. Az összes vizsgált betegségből csak három csoportban tapasztalható csökkenés a vizsgált 21 év alatt. Ezek a vakság és csökkentlátás, gyomor-és nyombélfekély, fiatalkori ízületi gyulladások. A növekedés mértéke 13 betegségnél 1,2-1,8-szoros, 11 betegségnél 2-3-szoros, 5 betegségnél 4-5-szörös, 3 betegségnél 6-8-szoros.

Egyes betegségek tételes alakulása betegségenként vagy betegségcsoportonként kerül bemutatásra.

A házorvosok által nyilvántartott daganatos betegek száma az 1999. évi 140 633-ról 2019-re meghaladta a 400 000-et, és a betegségcsoportba tartozó daganatok 1000 före vetített aránya is folyamatos növekedést mutat (2. ábra).

A 3. ábrán a nemenkénti és korcsoportos adatokból látható, hogy 1000 före vetítve a nyilvántartott rosszindulatú daganatos betegek aránya a közép korosztályban a nőknél, míg a 65 év felettieknél a férfiaknál magasabb. (Tekintettel arra, hogy a BNO csoport öszszevont, CoO-C97, e jelentés alapján az egyes daganatfajtákat nem lehet külön vizsgálni.) 
Jelentős számszerű változás történt a vérképzőszervi betegségek tekintetében is. 1999-ben 116506 eset (ennek 60\%-a volt vashiányos anaemia), 2019-ben: 525812 eset (melynek 44\%-a volt vashiányos anaemia). Az 1000 före vetített aránya a legutóbbi évekig egyenletes emelkedést mutatott (4. ábra).

Nemenként és korcsoportonként elemezve az adatokat, az 5. ábrán látható, hogy inkább nőkre jellemző e betegség, amely minden korcsoportban erőteljes növekedést mutat a vizsgált években.

A belső elválasztású mirigyek okozta betegségek száma 2019-re megközelítette a 2 milliót. Nagyobb arányban a pajzsmirigy rendellenességei nőttek (2019ben: 755623 eset az 1999. évi 92490 esethez képest). A diabetes mellitus esetek száma is két és félszeres lett a 21 év alatt: az 1999. évi 422 000-ről 2019-re 1097 582-re növekedett). 1000 före vetítve a 6 . ábrán láthatóak az eredmények mindkét betegség vonatkozásában.

A pajzsmirigy betegségek jellemzően a nőket érintik. A 7. ábrán látható, hogy a betegség 1000 före vetítve minden korcsoportban - a legfiatalabban is egyenletes növekedést mutat.

A diabetes mellitus a középkorúaknál mérsékelten emelkedik, egy ideje stagnál, az idősebb korban viszont folyamatosan növekszik (8. ábra). A közép és idősebb korosztályban is 1000 före viszonyítva több a férfi beteg, mint a nő.

Az egyéb endokrin mirigyek rendellenességeinek száma 51756 volt 2019-ben, ez is megduplázódott 1999-hez képest.

A szív - és érrendszeri betegségek változását az azokkal szoros kapcsolatban levő lipoprotein-anyagcsere zavarokkal együtt mutatjuk be. Abszolút számokkal kifejezve a magas vérnyomás 3,16 millió, a lipoprotein-anyagcserezavar 1,39 milló, az ischaemiás szívbetegség 1,27 millió, a cerebrovasculáris betegségek 610000 embert érintettek 2019-ben. A 9. ábrán látható, hogy a 2010-es évek közepétöl több betegségnél is lassult, illetve megállt a növekedés.

Mind a négy vizsgált betegség tekintetében elmondható, hogy a középkorosztályban az utóbbi időben inkább enyhe csökkenés látható, és az idősebb korosztályban is megállt a növekedés az 1000 före vetített betegek számában (9. ábra). A magas vérnyomás tekintetében a két nemben alig különbözik az arány, ellenben az ischaemiás szívbetegségeknél, cerebrovasculáris betegségeknél, de lipoprotein-anyagcsere betegségeinél is többnyire a férfiaknál magasabb az 1000 före jutó betegségek száma (10-13. ábra).
Az idült légzőszervi betegségek emelkedése töretlennek tűnik (14. ábra), számuk lényegesen meghaladja az asztmáét, viszont az utóbbi növekedése meredekebb volt a vizsgált időszakban. Míg az idült légút betegségek kétszeresre nőttek, az asztmánál négyszeres emelkedést könyvelhetünk el 21 év alatt.

Együttesen mintegy 1 millió krónikus légzőszervi megbetegedés szorul kezelésre, ebből 60\% idült alsó légúti betegség, 40\% az asztma.

Az emésztőszervi betegségek között észlelhető csökkenés is (17. ábra). A gyomor-és nyombélfekélyek száma 2007. évtől csökken. Az alkoholos májbetegségeket csak 2009. évtől regisztrálják a háziorvosok, számuk 2011. évtől a jelentett adatok alapján csökken. A legmagasabb számban - 201000 - a májbetegségek fordulnak elő. A fekéllyel diagnosztizáltak száma összesen 161000 före csökkent. Ebben a körben legmeredekebb - háromszoros - emelkedést a colitis ulcerosa, egyéb nem fertőzéses eredetű vékony- és vastagbélgyulladások mutatnak, számuk 2019-ben meghaladja a 160 ezret. A 18. ábrán látható, hogy ez a betegségcsoport a legfiatalabb felnőtt korosztályt épp olyan mértékben érinti, mint az időseket.

A vesebetegségek változása a vizsgált két betegség vonatkozásában figyelemre méltó. A glomeruláris betegségek, renalis tubulointerstitialis betegségek száma mérsékelten emelkedett, viszont a veseelégtelenség száma közel 9-szeresére nőtt a háziorvosi nyilvántartásban. E betegségnek a nemenkénti és korcsoportos alakulása a 19. ábrán látható.

A mozgásszervi betegségek közül enyhe emelkedés észlelhető a köszvény és a csontsűrüség, csontszerkezet rendellenességei tekintetében, viszont a spondylopathiák száma 2005-től meredeken - több mint 4-szeresére - nőtt (21. ábra). A seropozitív és egyéb rheumatoid arthritis száma gyakorlatilag változatlan volt a vizsgált időszakban.

A jelentésben szereplő érzékszervi betegségek közül a vakság és csökkentlátás mutat javuló tendenciát, a szem egyéb betegségeinek száma viszont meredeken emelkedik (22. ábra). 2013-tól érzékelhető növekedés a vezetéses típusú, idegi eredetú és egyéb hallásvesztés tekintetében is.

Az idegrendszer szervi és funkcionális elváltozásai átlagosan 2,2-szeresre nőttek. Ennél is nagyobb mértékben az Alzheimer-kór és az extrapyramidális és mozgási rendellenességek emelkedtek (23. ábra). Az egyes betegségek száma nem éri el a 100000 föt, így az 1000 före vetített aránytól és további alábontásoktól (nemek, korcsoportok) eltekintettünk. 
(E00-E07) Pajzsmirigy rendellenességei (N17-N19) Veseelégtelenség

(M10) Köszvény

(E78) Lipoprotein-anyagcsere rendellenességei (D50-D89) A vér és vérképző szervek betegségei (M45-M49) Spondylopathiák (J45) Asthma

(K50-K52) Nem fert. bélgyulladás

(D50) Vashiányos anaemia

(C00-C97) Rosszindulatú daganatok (160-169) Cerebrovascularis betegségek

(E10-E14)Diabetes mellitus (G30) Alzheimer-kór

(J40-J44) Idült alsó légúti betegségek közül (G40) Epilepsia (M80-M85) Osteoporosis

(E20-E35) Egyéb endokrin mirigyek rendell.

(I10-I15) Magasvérnyomás betegségek (F20-F29) Schizophrenia, delusiv rendellenességek (G35) Sclerosis multiplex

(G45, G46) Átmeneti agyi isch.att.(TIA)

(120-125) Ischaemiás szívbetegségek

(105-109) Idült rheumás szivbetegségek (134-139) Szívbetegségek egyéb formái közül

(H90, H91) Vezetéses típ. hallásvesztés

(M05, M06) Seropositiv rhe umatoid arthritis

(F10-F19)Pszichoaktív szer okozta ment.zavar

(N00-N08), (N10-N16) Vese betegségek (F70-F79) Mentális retardatio

(M40-M43) Deformáló hátgerinc-elváltozások (K70-K77) A máj betegségei (M08) Fiatalkori izületi gyulladás (K25-K28) Gyomor-, nyombélfekély (H54) Vakság és csökkentlátás

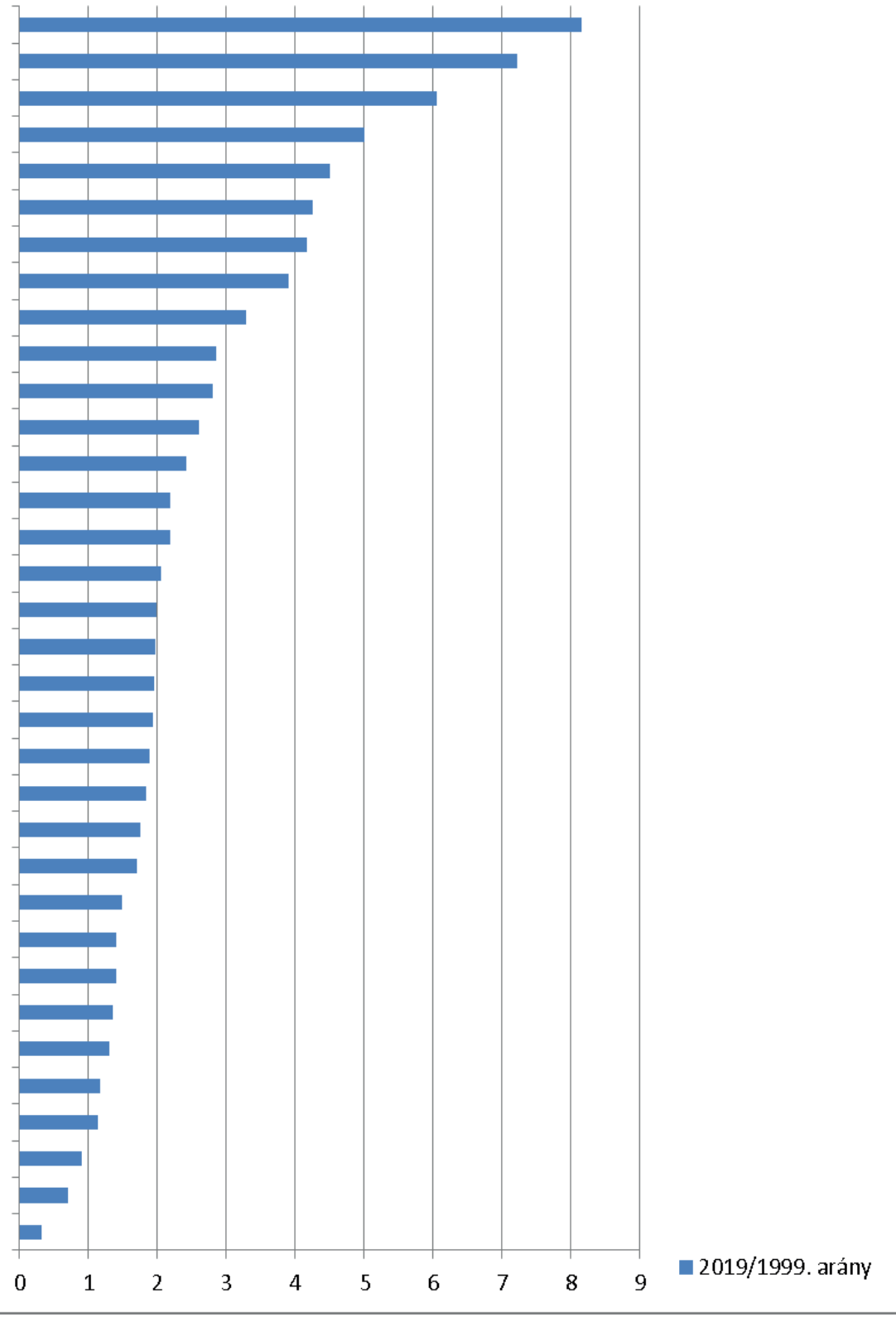

7. ábra: A háziorvosok által OSAP 1021 alapján jelentett betegségekkel nyilvántartott felnōttek számának változása 1999-2019. években Magyarországon 


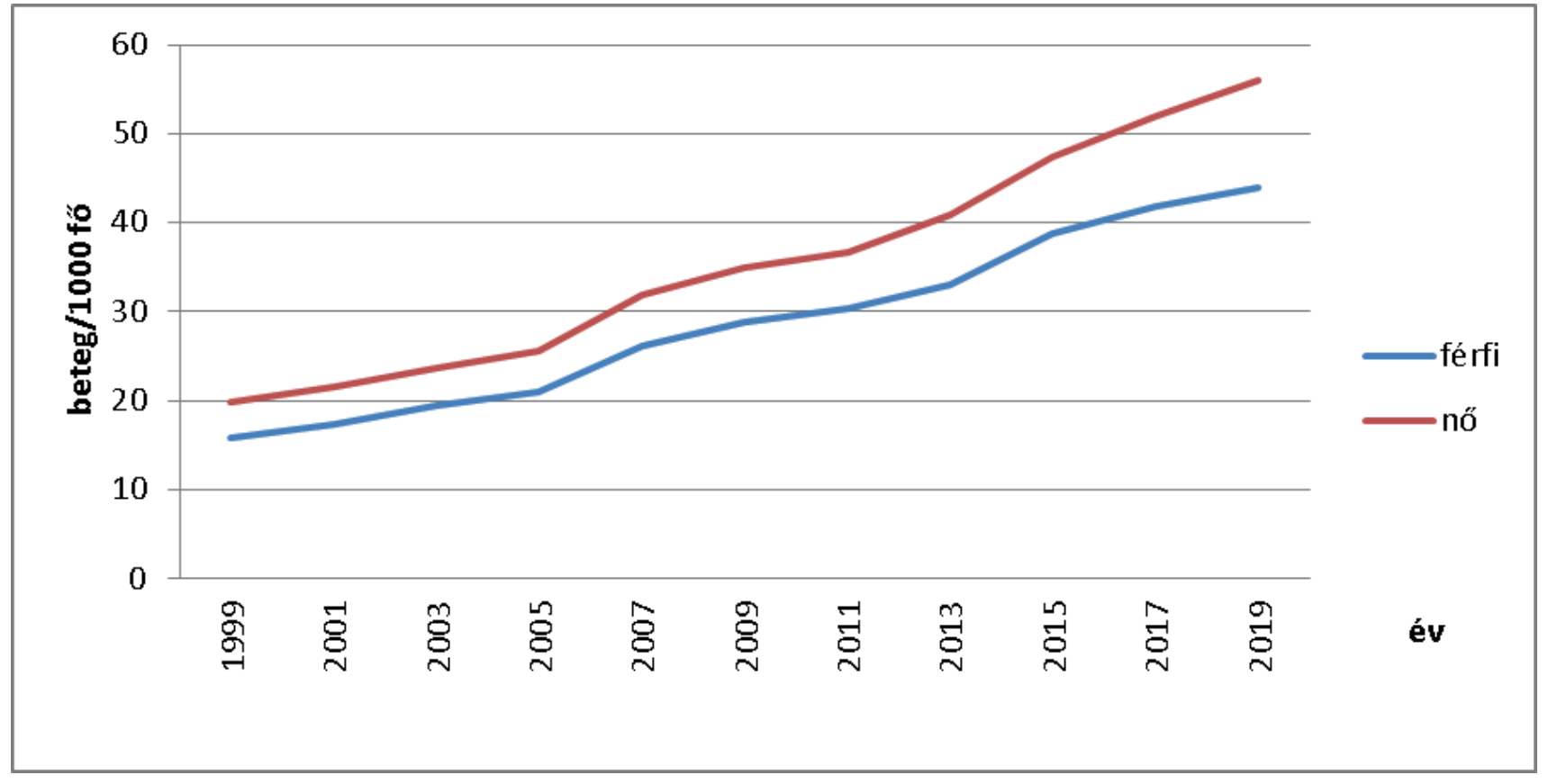

2. ábra: A rosszindulatú daganatos betegek arányának változása az OSAP 1021 jelentés alapján a felnőtt lakosság körében 1000 före, nemenként az 1999-2019. években Magyarországon

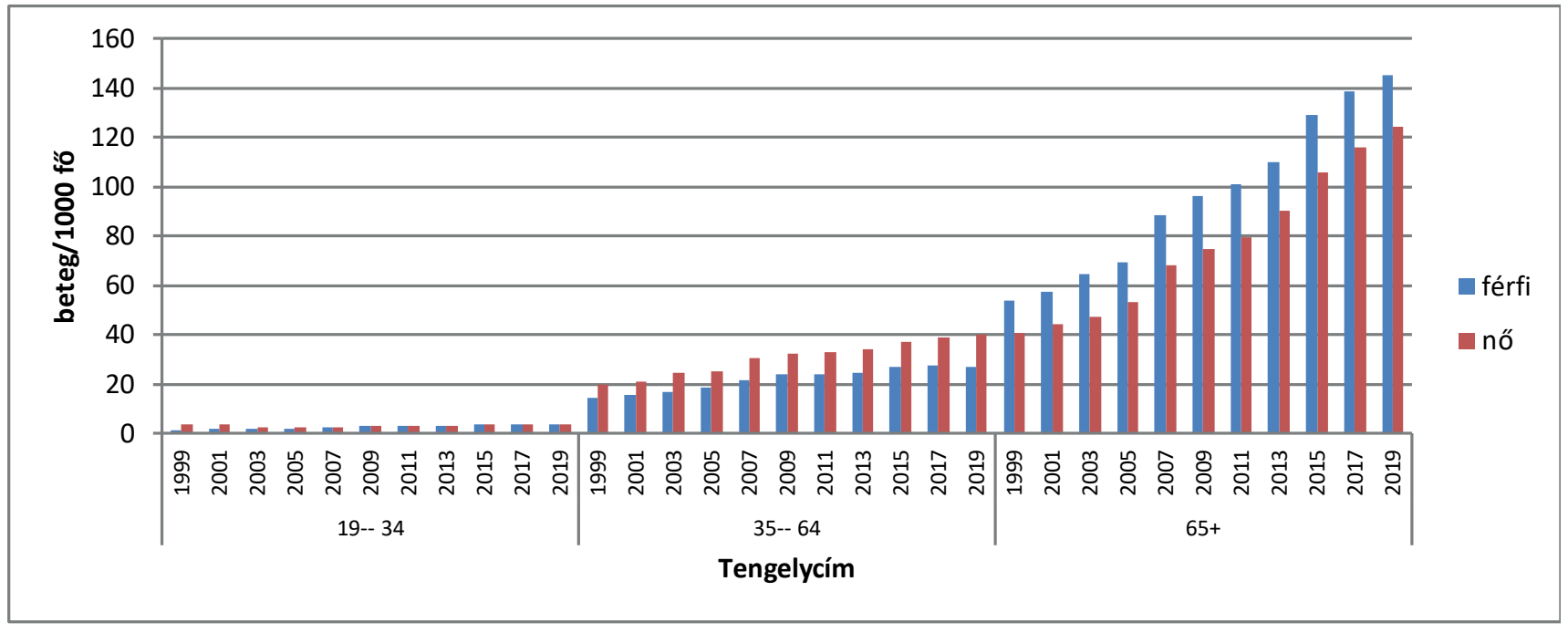

3. ábra: Rosszindulatú daganatos megbetegedések az OSAP 1021 alapján a felnött lakosság körében 1000 före, nemenként és korcsoportonként, 1999-2019. Magyarország 


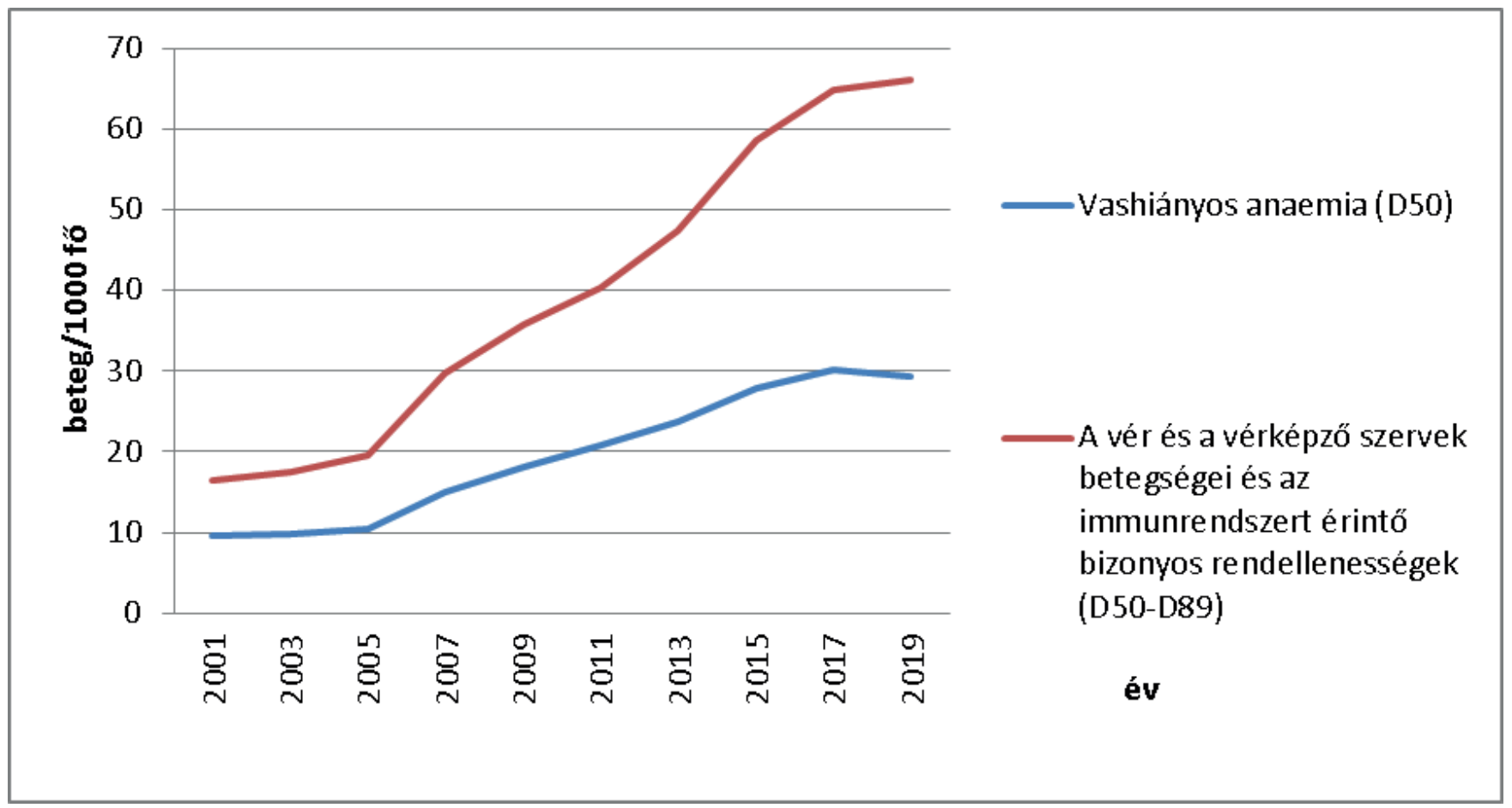

4. ábra: A vért és vérképző szerveket és az immunrendszert érintő betegségek az OSAP 1021 alapján a felnőtt lakosság körében 1000 före az 1999-2019. években Magyarországon

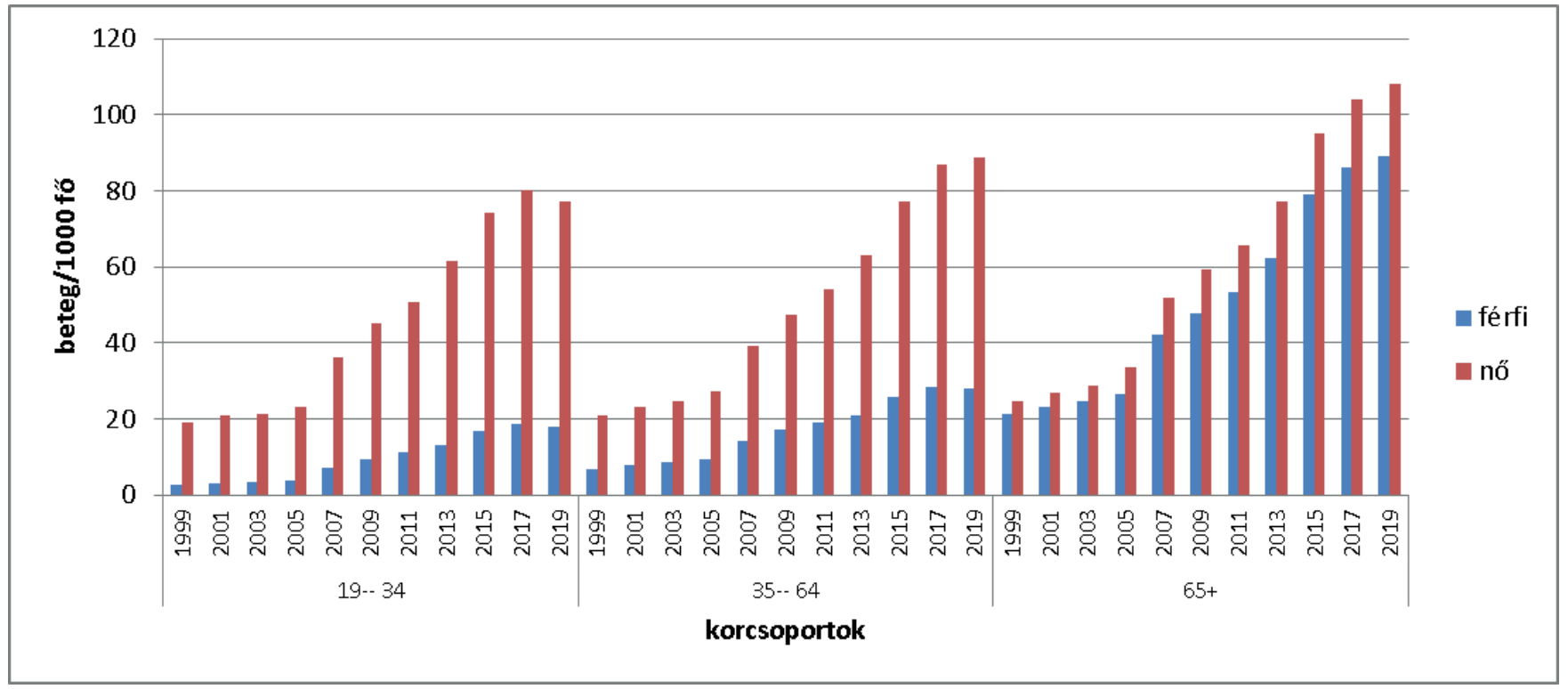

5. ábra: A vért és vérképzőszerveket és az immunrendszert érintő betegségek az OSAP 1021 alapján felnőtt lakosság körében, 1000 före nemenként és korcsoportonként, 1999-2019., Magyarország 


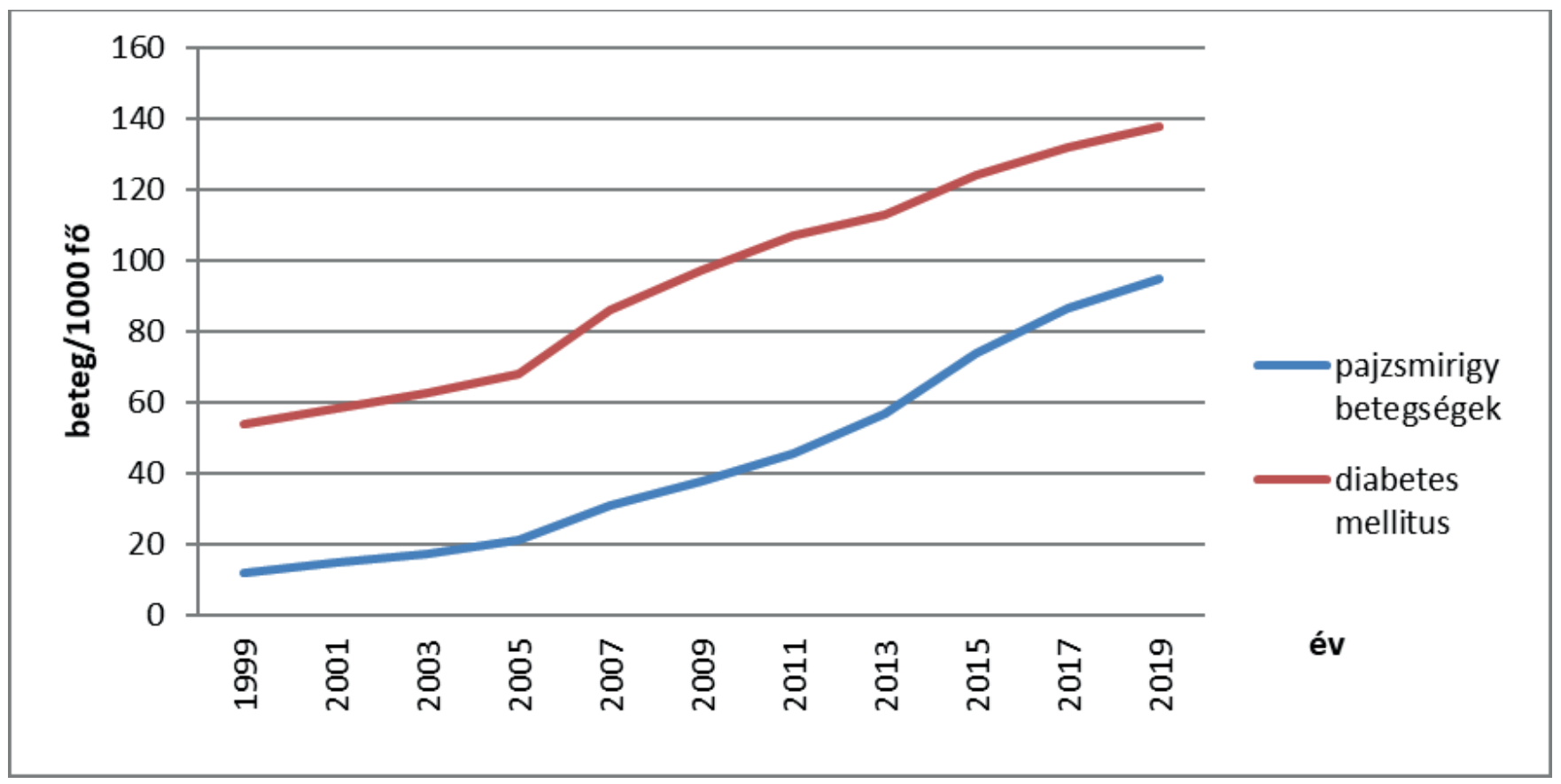

6. ábra: A pajzsmirigy rendellenességei és a diabetes mellitus az OSAP 1021 alapján a felnött lakosság körében 1000 före az 1999-2019. években Magyarországon

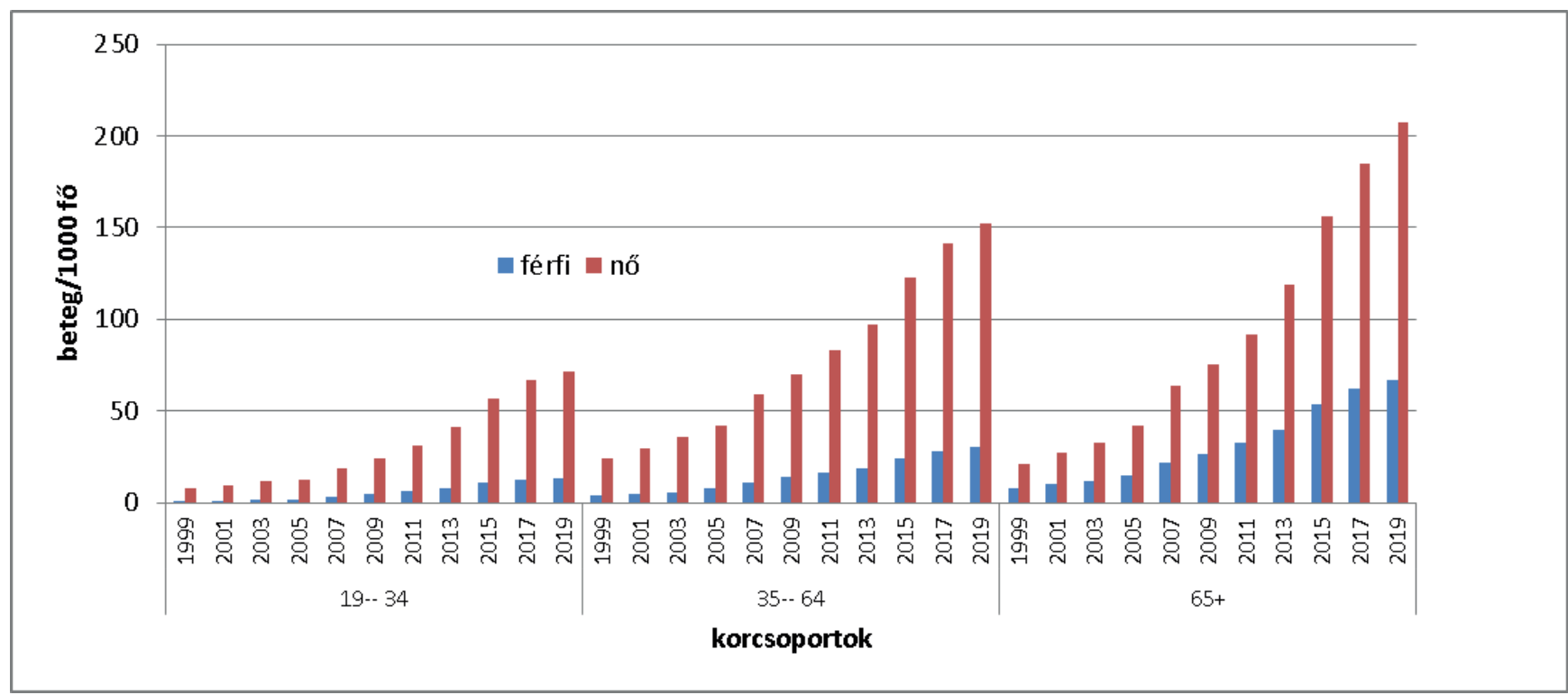

7. ábra: A pajzsmirigy rendellenességei az OSAP 1021 alapján a felnött lakosság körében, 1000 före nemenként és korcsoportonként, 1999-2019., Magyarország 


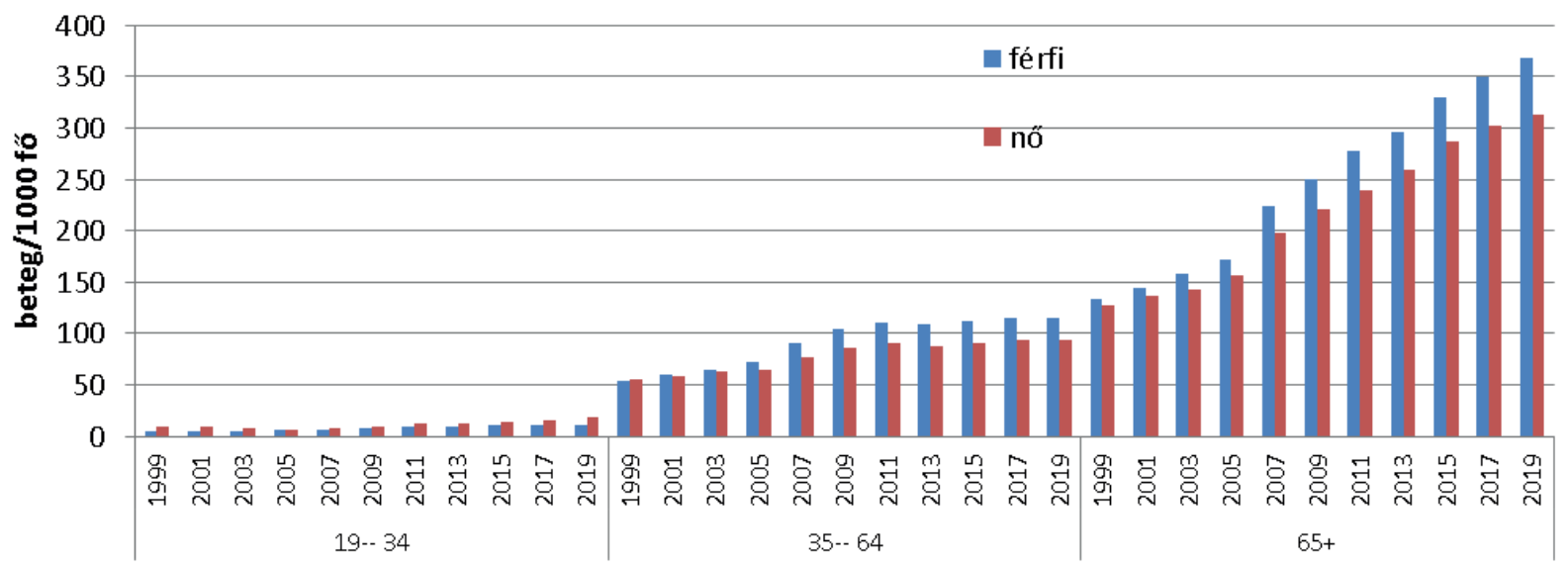

korcsoportok

8. ábra: Diabetes mellitus az OSAP 1021 alapján felnőtt lakosság körében, 1000 före nemenként és korcsoportonként, 1999-2019., Magyarország

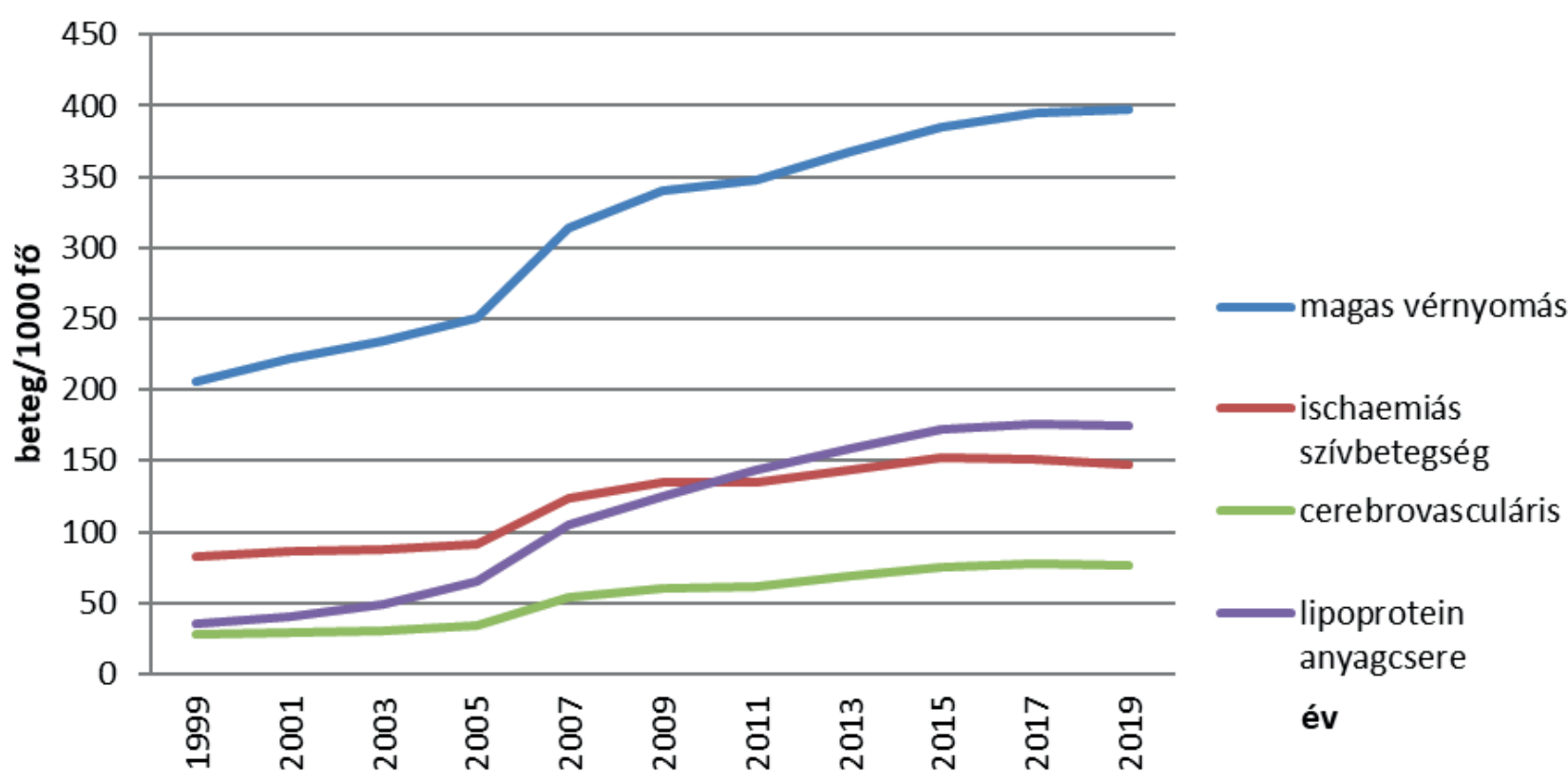

9. ábra: Egyes szív- és érrendszeri betegségek és lipoprotein-anyagcsere zavarok az OSAP 1021 alapján a felnőtt lakosság körében 1000 före, 1999-2019., Magyarország 


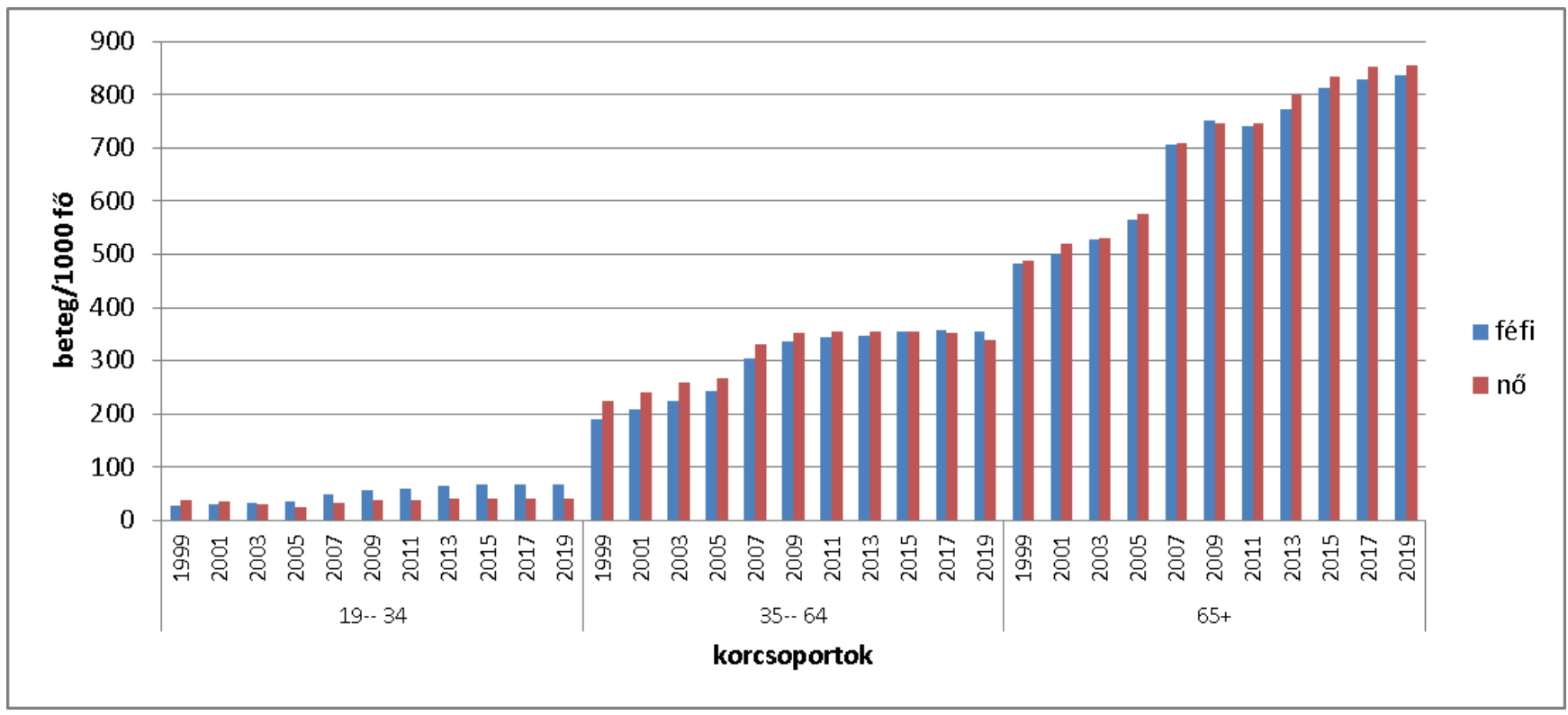

10. ábra: Magas vérnyomás betegségek az OSAP 1021 alapján a felnőtt lakosság körében 1000 före, nemenként és korcsoportonként, 1999-2019., Magyarország

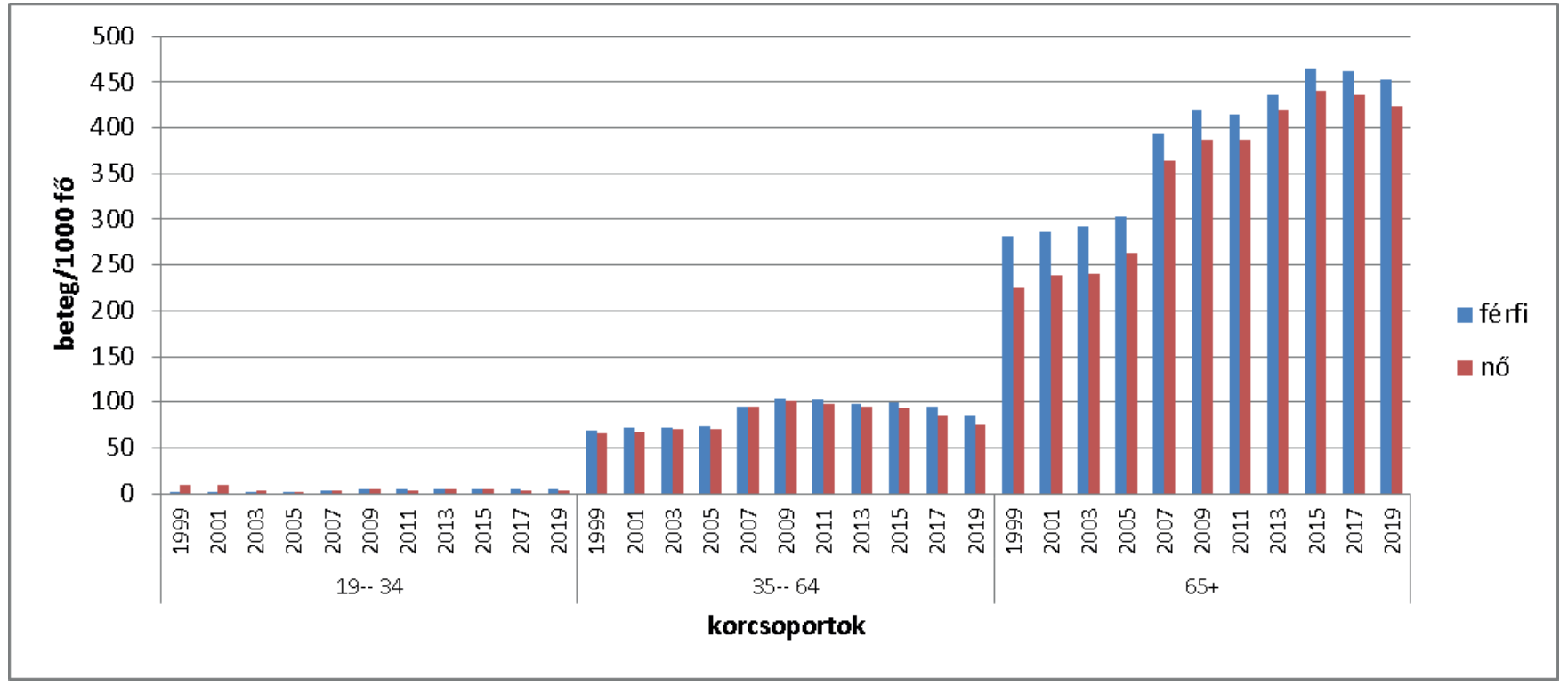

11. ábra: Ischaemiás szívbetegségek az OSAP 1021 alapján a felnöttek körében 1000 före, nemenként és korcsoportonként, 1999-2019., Magyarország 


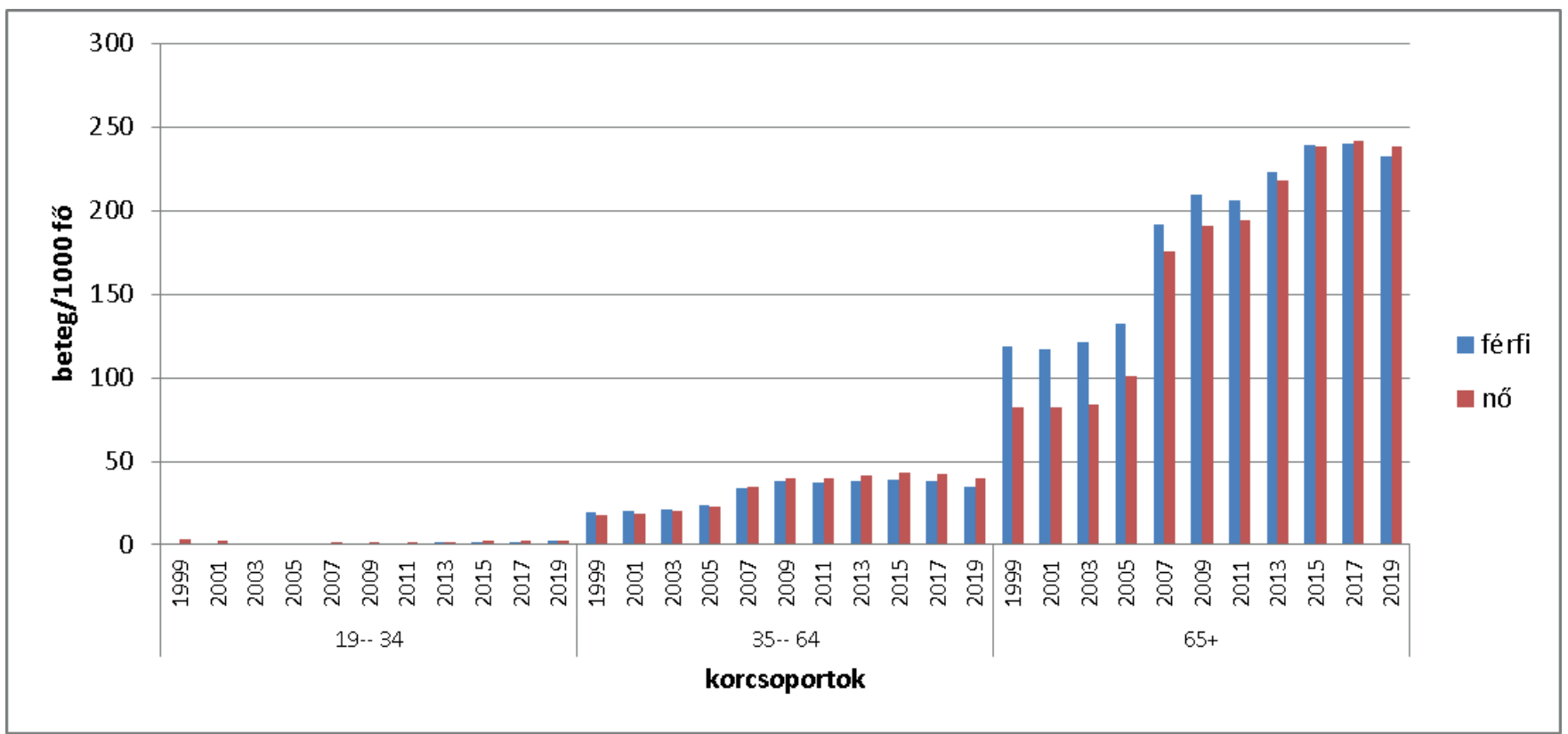

12. ábra: Cerebrovasculáris betegségek az OSAP 1021 alapján a felnöttek körében 1000 före, nemenként és korcsoportonként, 1999-2019., Magyarország

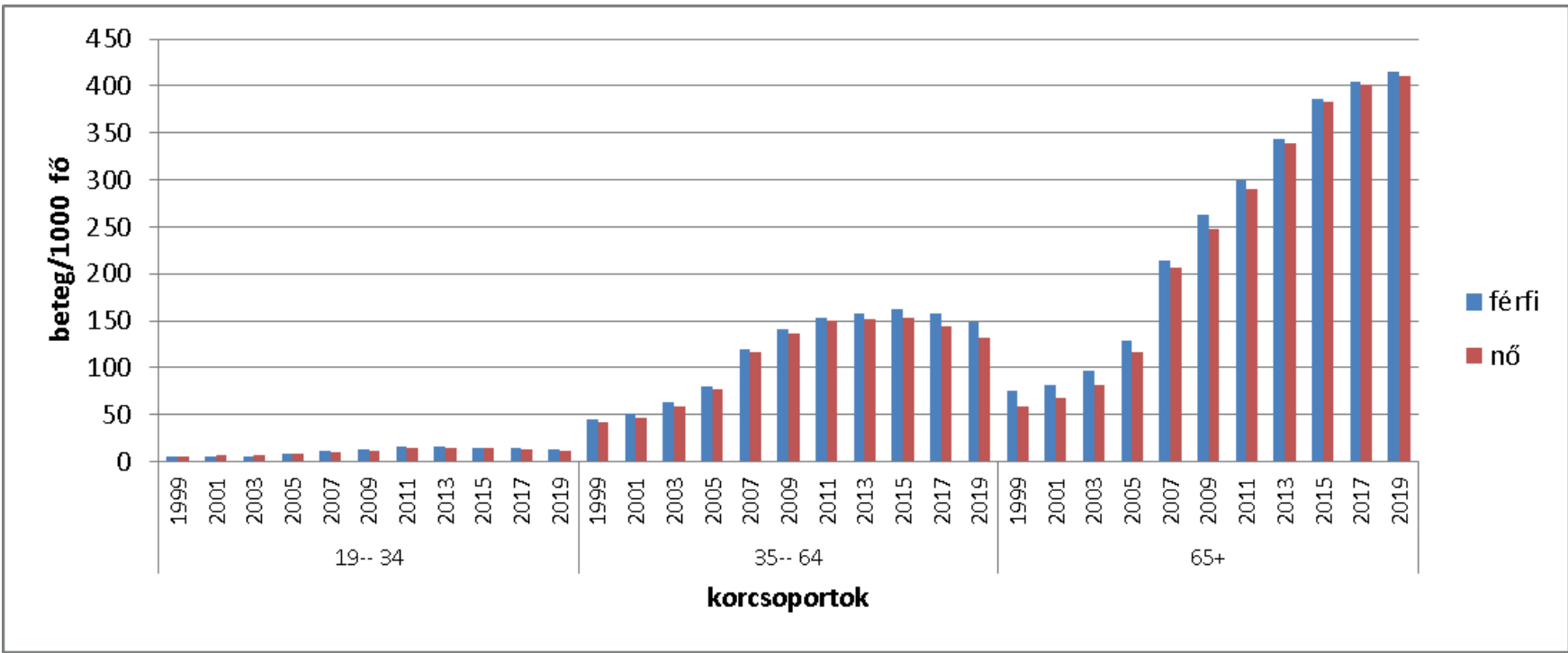

13. ábra: A lipoprotein-anyagcsere rendellenességei az OSAP 1021 alapján 1000 före, nemenként és korcsoportonként, 1999-2019., Magyarország 


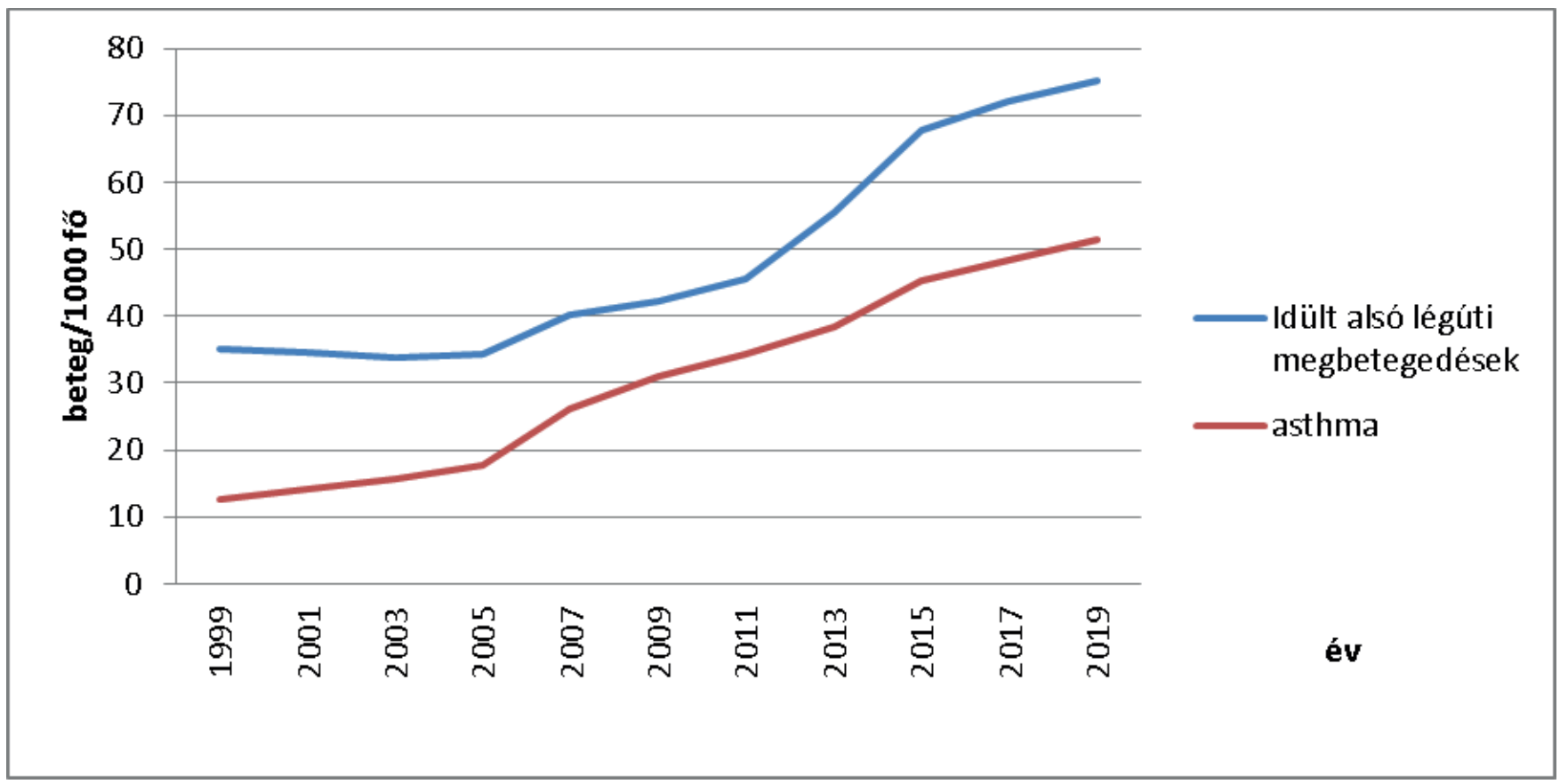

14. ábra: Idült alsó légúti betegségek és asztma az OSAP 1021 alapján a felnôtt lakosság körében 1000 före az 1999-2019. években Magyarországon

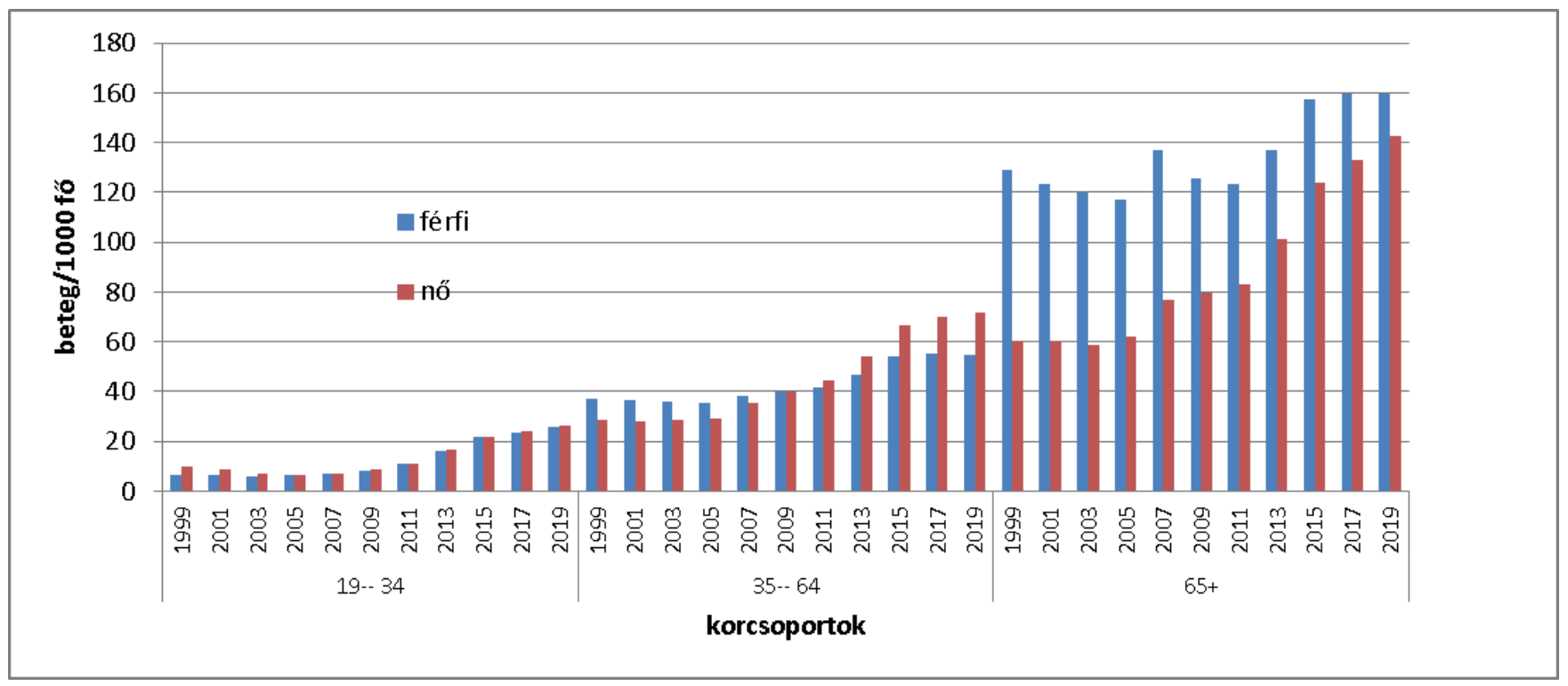

15. ábra: Idült alsó légúti megbetegedések az OSAP 1021 alapján felnött lakosság körében 1000 före, nemenként és korcsoportonként, 1999-2019., Magyarország 


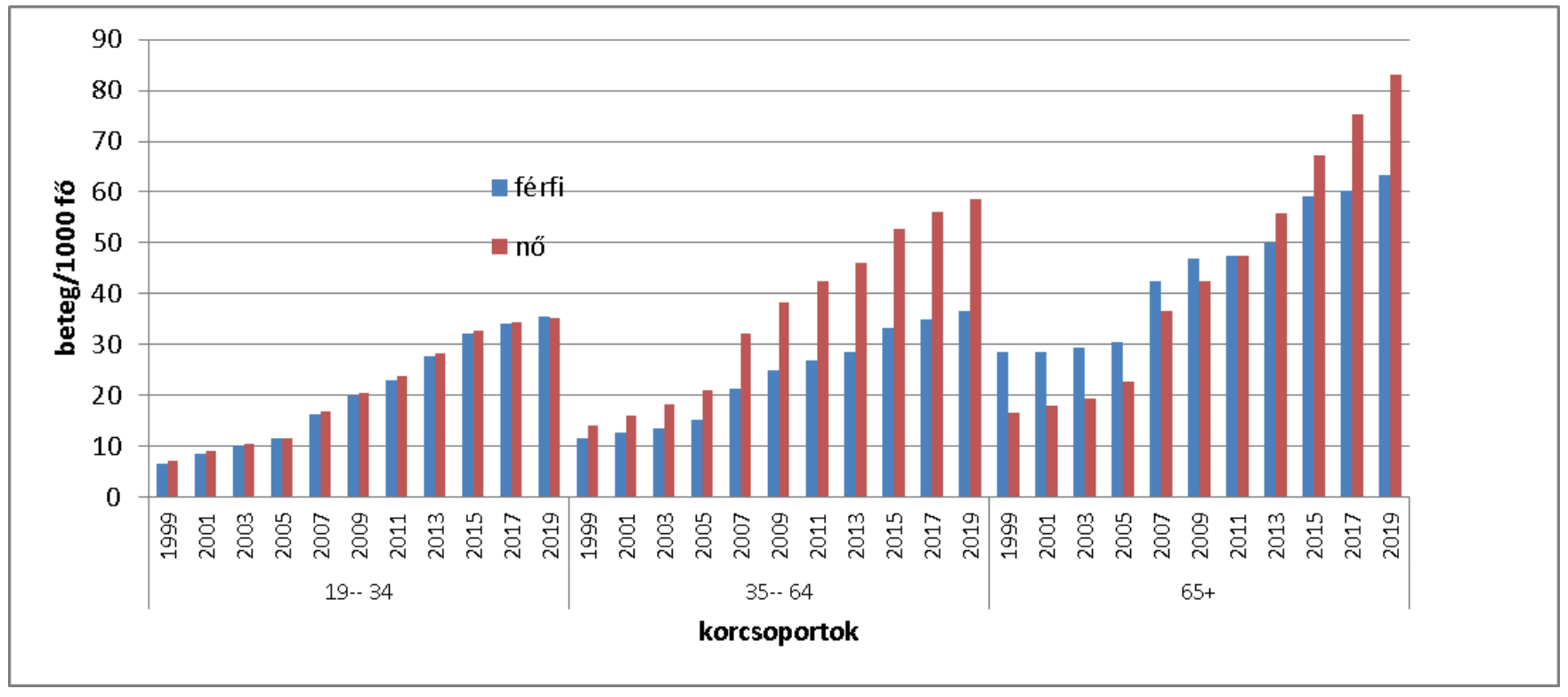

16. ábra: Asztma az OSAP 1021 alapján felnőttek körében 1000 före, nemenként és korcsoportonként, 1999-2019. években Magyarország

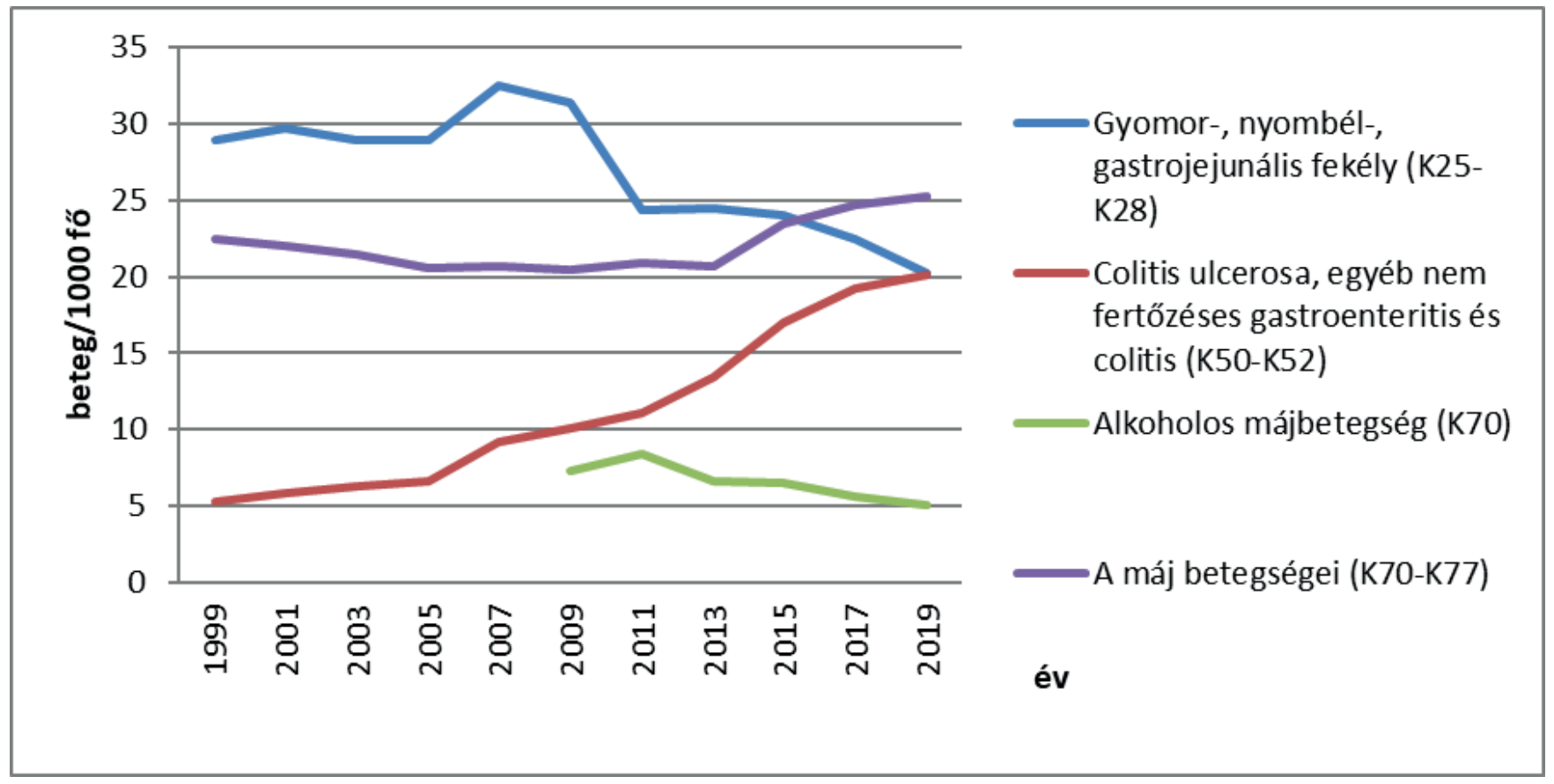

17. ábra: Egyes emésztőszervi betegségek az OSAP 1021 alapján a felnött lakosság körében 1000 före, az 1999-2019. években Magyarországon 


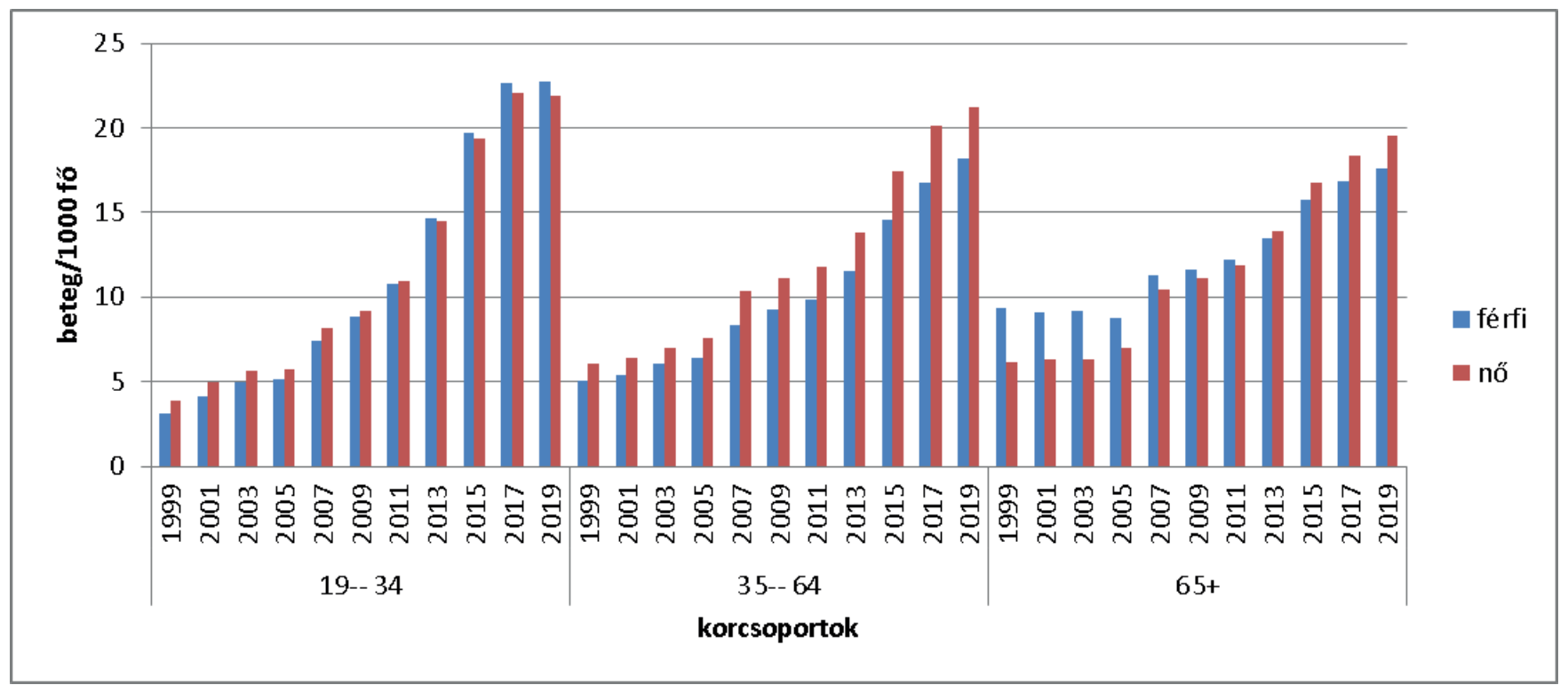

18. ábra: Colitis ulcerosa és egyéb nem fertőzéses gastroenteritis és colitis az OSAP 1021 alapján felnôttek körében, nemeként és korcsoportonként, 1999-2019., Magyarország

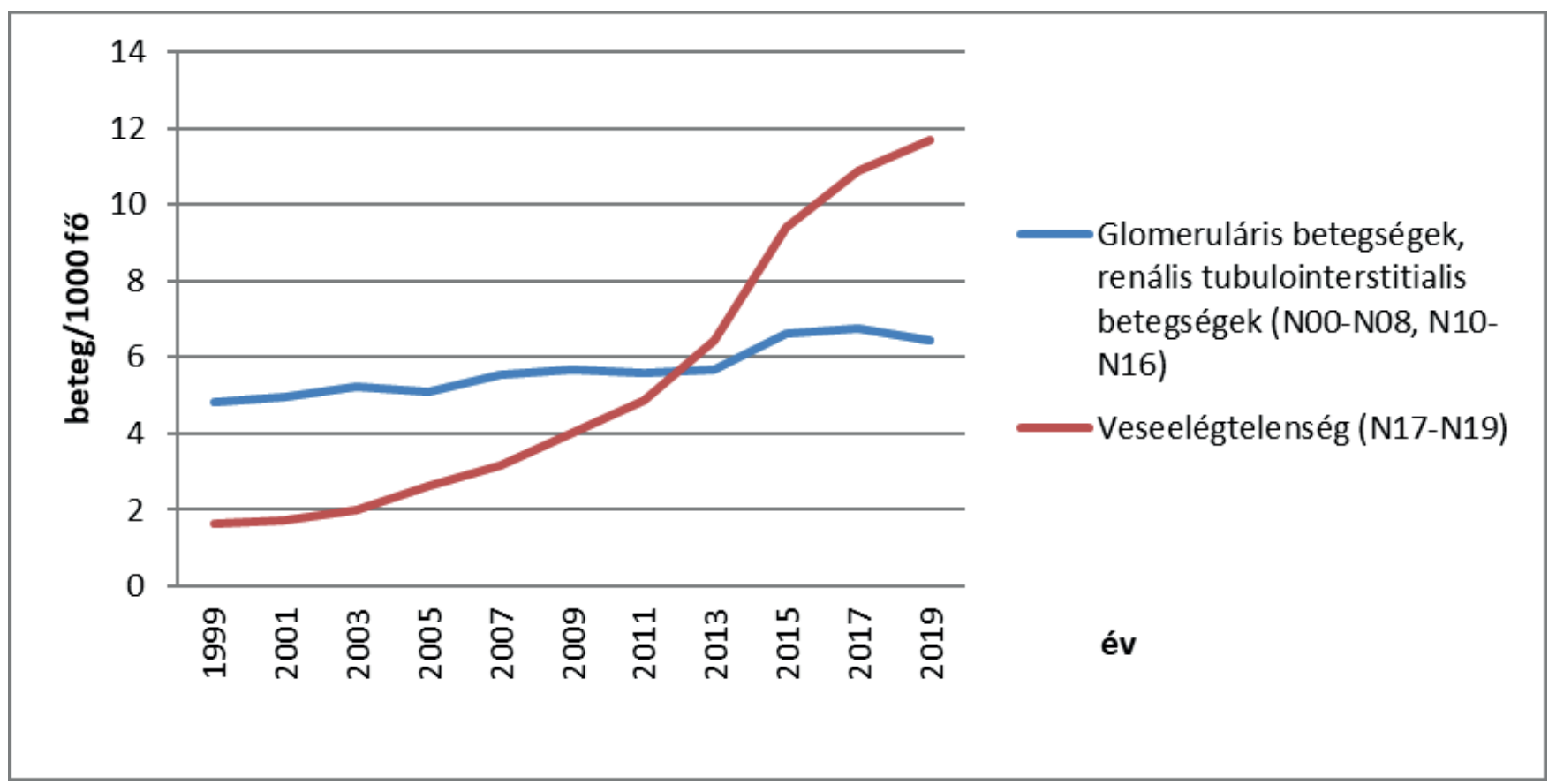

19. ábra: Egyes vesebetegségek az OSAP 1021 alapján a felnőtt lakosság körében 1000 före az $1999-2019$. években Magyarországon 


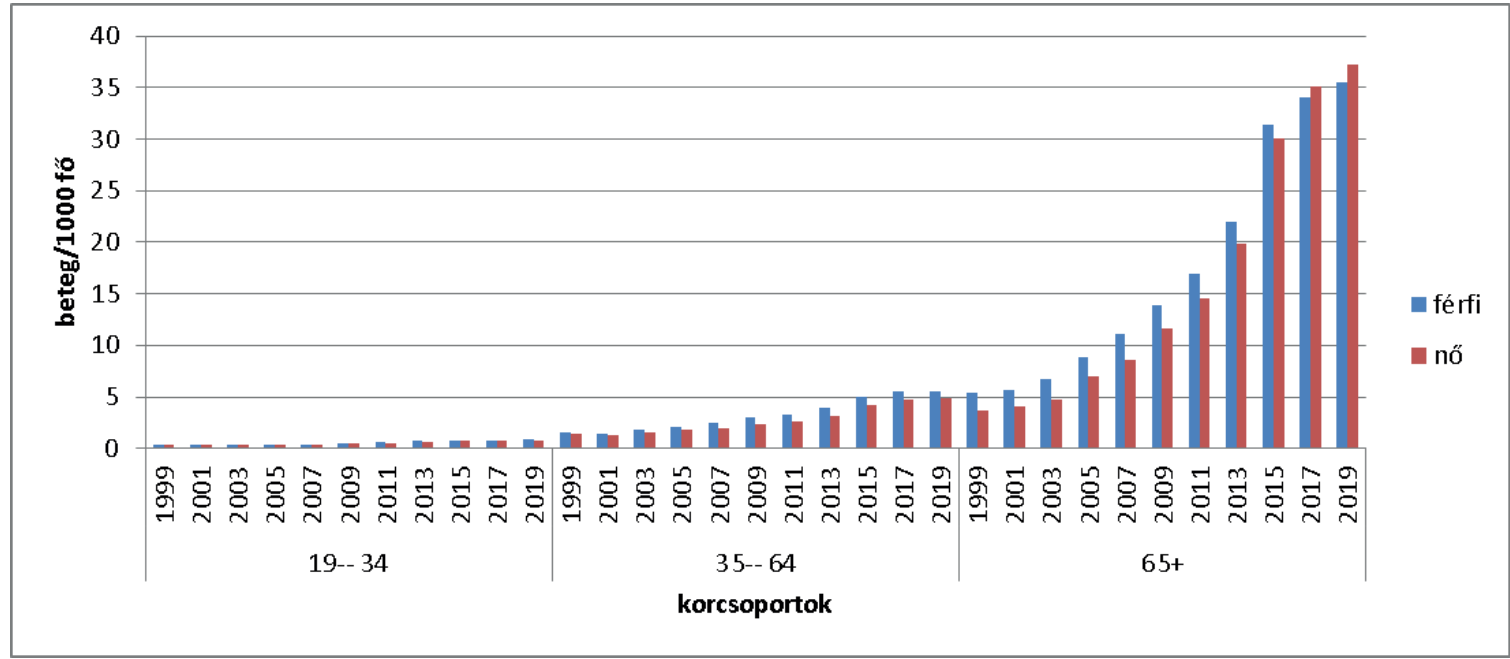

20. ábra: Veseelégtelenség az OSAP 1021 alapján felnöttek körében, nemenként és korcsoportonként, 1999-2019., Magyarország

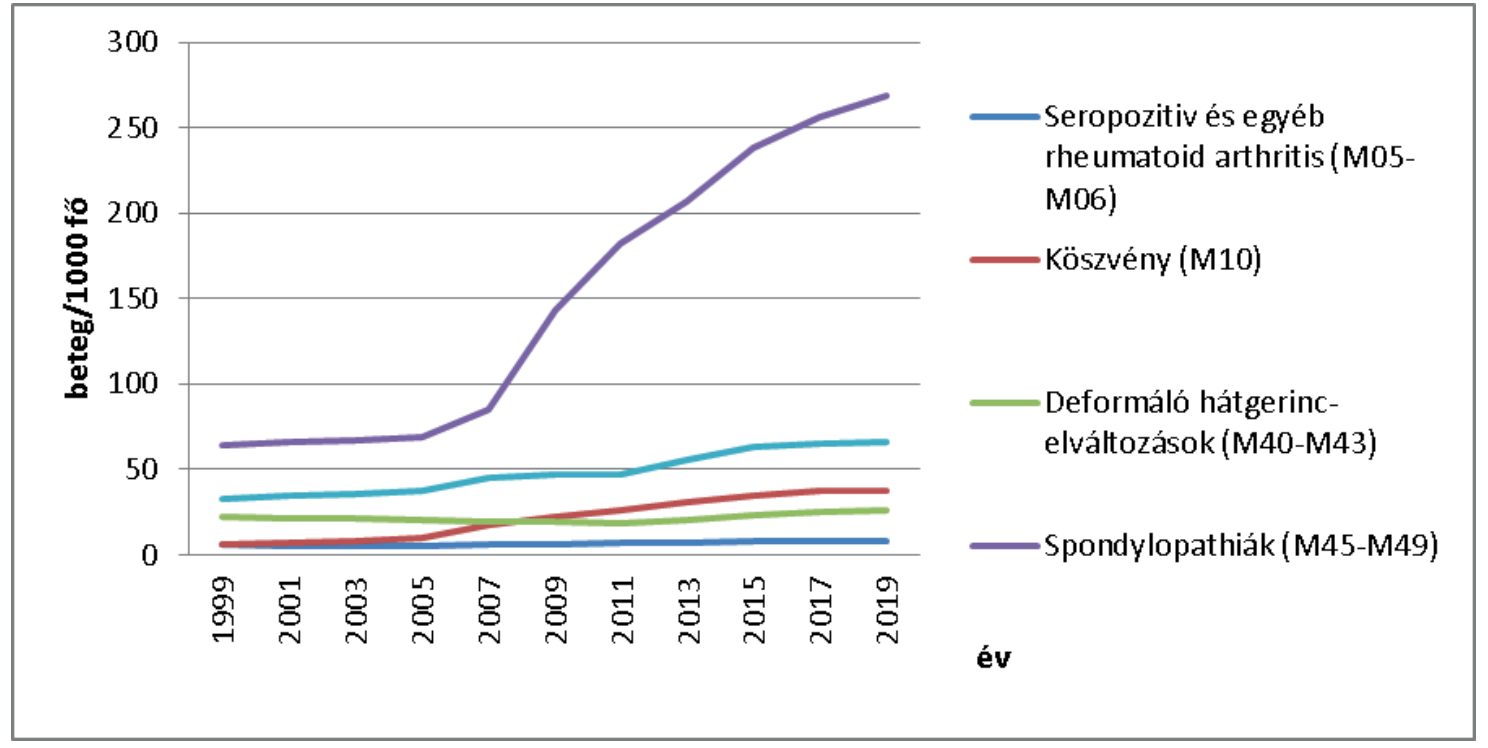

21. ábra: Egyes mozgásszervi betegségek alakulása a felnőtt lakosság körében 1000 före az 1999-2019. években Magyarországon 


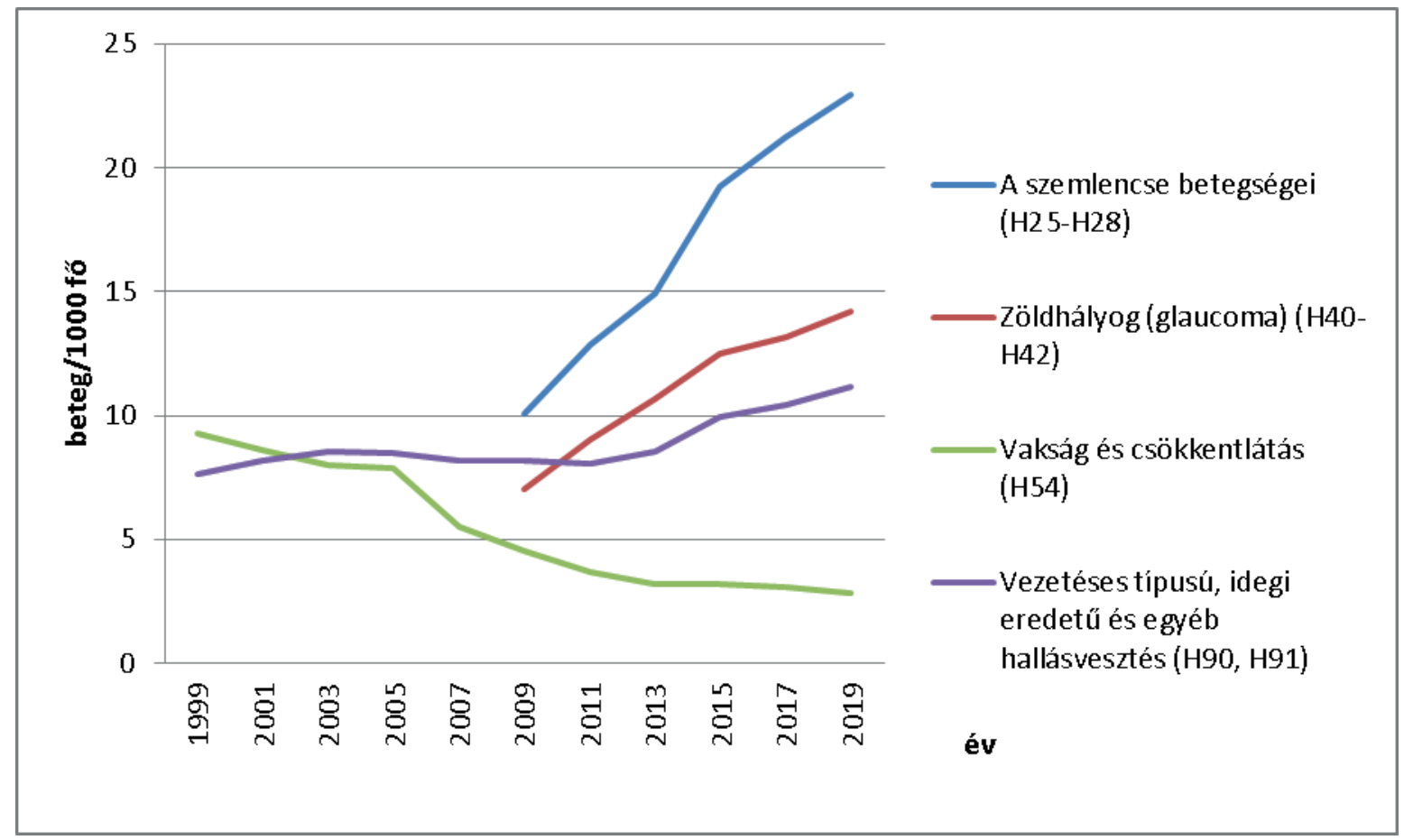

22. ábra: Egyes érzékszervi betegségek alakulása az OSAP 1021 alapján a felnött lakosság körében 1000 före az 1999-2019. években Magyarországon

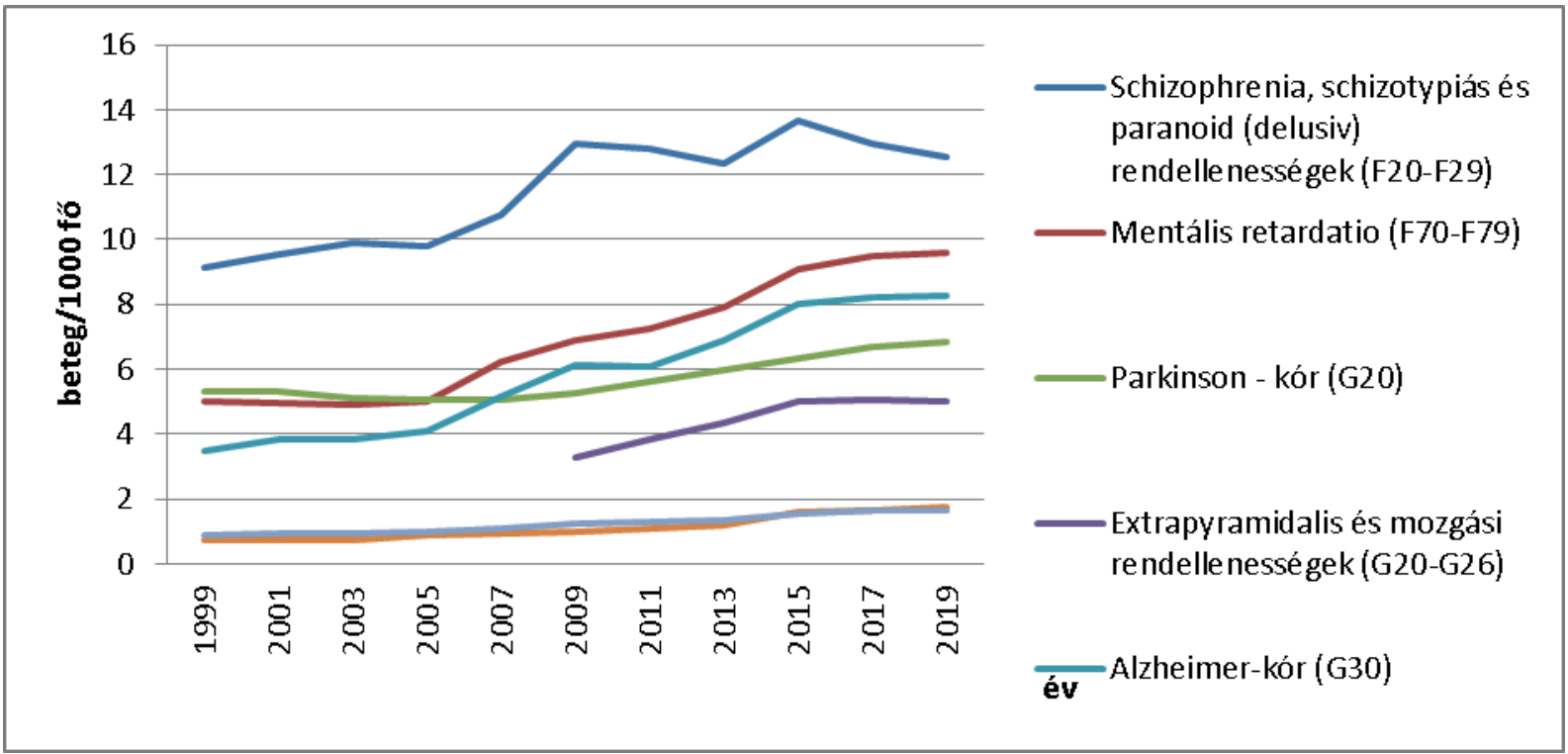

23. ábra: Psychés és idegrendszeri megbetegedések száma az OSAP 1021 jelentések alapján a felnőtt lakosság körében 1000 före az 1999-2019. években Magyarországon 


\section{Megbeszélés}

A háziorvosi jelentésekből látható, hogy az összes gondozást igénylő betegség száma 2019. évben meghaladta a 15 milliót a 19 év felettiek körében. Tehát, egy felnőtt emberre közel 2 krónikus megbetegedés jut hazánkban.

A betegségek számának növekedése mögött több ok is lehet. Ezek közül az alábbiakat vesszük számba:

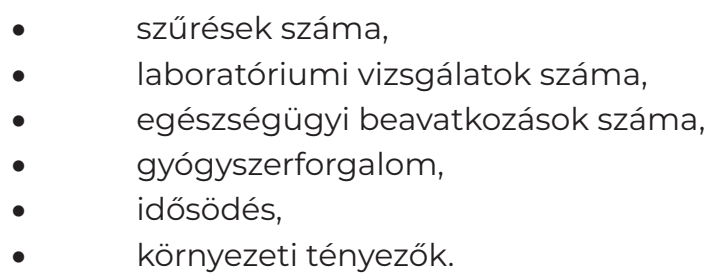

Az adatok forrásai szúrések, laboratóriumi vizsgálatok és beavatkozások tekintetében a járóbeteg szakellátás jelentések, a mútétek esetén a fekvőbeteg szakellátás jelentések, míg a gyógyszerek vonatkozásában a vényforgalmi jelentések voltak. Mindezeket az adatokat a Nemzeti Egészségbiztosítási Adatkezelő (NEAK) bocsátotta rendelkezésünkre.

\section{Szürések}

A rosszindulatú daganatos betegségek növekedése mögött állhat a szűrésben résztvevők számának emelkedése. A NEAK adatai szerint emlőszűrésen 1999-ben 234343 fő vett részt, 2019-ben 473 041. Nőtt a prosztata szúrésen résztvevők száma is 20 év alatt. 1999-ben 70820 fő, 2019-ben 188387 fö jelent meg dülmirigy szűrésen. A méhnyak szürésre vonatkozóan 1999. évi adatok nem állnak a NEAK rendelkezésére, 2019-ben 519944 fötől vettek méhnyak kenetet.

A szürések, mint köztudott, a szekunder prevenció eszközei. A szűrések hatékonysága, mely a daganatos halálozási adatok csökkenésével mérhető, nagyban függ attól, hogy milyen a részvételi arány, illetve, hogy megfelelő időben történik-e a szűrés. Az emlőrák esetén a kívánatos átszürtség 70\%, mely a WHO szerint 20-30\%-kal csökkenti az emlörák halálozást ${ }^{8}$. Hazánkban a szürési hajlandóság 38,8\% volt a 2010-es években az átlag populációban, és a daganatos betegek körében is. Az elmúlt 30 évben nem csökkent a daganatos halálesetek száma.

Érdemi megelőzés a primer prevencióban rejlik. Az EU 2020. évi rák ellenes világnapon megerősítette, hogy a rosszindulatú daganatok 40\%-a megelőzhető lenne ${ }^{10}$ Kiemelten foglalkozni kellene az Európai Parla- ment (EP) szerint a munkahelyi rákkeltőkkel is, hiszen a foglalkozással összefüggő halálesetek háttérében mintegy 53\%-ban ez a betegség áll"

\section{Laboratóriumi vizsgálatok}

A laboratóriumi vizsgálatok száma is nőtt 21 év alatt.

Vér- és vérképzőszervi betegségek kapcsán 1999ben 3068185 beteget vizsgáltak, míg 2019-ben 4213 670-et. A betegek száma több, mint 1 millióval, a vizsgálatok száma 3,8 millióval (6,7 millióról 10,5 millióra) nőtt. A gyorsabb és pontosabb laboratóriumi módszerek, melyek teljesebb vérképet mutatnak, hozzájárulhattak a rendellenességek kimutatásához. A vérképzőszervi betegségek száma magas és növekvő tendenciát mutat. Ennek az örökletes tényezők mellett környezeti okai is vannak. Vashiányos anaemia esetén például a táplálkozást (a táplálék összetevőket) nem lehet figyelmen kívül hagyni.

Az endokrin rendszerre vonatkozó vizsgálatok száma is jelentősen megnőtt. Az elvégzett glükóz vizsgálatok száma 7 millióról 9 millióra nőtt 1999-ről 2019-re. A vizsgálatot 1999-ben 2,9 millió betegnél végezték el, 2019-ben már 4 milliónál.

A pajzsmirigy hormon vizsgálatok száma 1999-ben 142065 eset, 2019-ben 262379 eset volt. A TSH vizsgálatok száma megháromszorozódott: 7571-ről 24 177-re emelkedett 21 év alatt. A pajzsmirigy érintettsége nyilvánvaló, jelentős részben ún. autoimmun folyamatok állnak a háttérben².

Vérzsírszintet 1999-ben 1,7 millió betegnél vizsgáltak 2,6 millió esetben, 2019-ben 3,1 millió betegnél 4,8 millió esetben. A szív és érrendszeri betegségek magas száma - ami szoros összefüggésben van az elhízással is - indokolja a nagyszámú vizsgálatot.

Igen jelentősen nőtt a májfunkciós vizsgálatok száma is. 1999-ben 2,3 millió betegnél 4,1 millió vizsgálat volt, míg 2019-ben 3,9 millió betegnél 8,08 millió (!) vizsgálat történt.

A laboratóriumi vizsgálatok rendkívül fontosak a diagnózis szempontjából. Az emelkedő morbiditási adatok - különösen az elhízással összefüggő esetek azonban azt is jelzik, hogy a lelet kézhezvételét követően nem feltétlenül következik be jelentős változás a beteg életében.

\section{Kórházi beavatkozások}

A koronaér tágításra vonatkozóan csak 2019. évi adat áll rendelkezésre: 12090 betegen történt beavatkozás, ami növelhette a betegek túlélési esélyeit. A halálozási adatok kedvezően alakultak, bár EU-s viszonylatban még mindig magasak. Az acut myocardiális infarctus 
miatt bekövetkező halálozások száma 2005-2015. között mintegy felére csökkent ${ }^{13}$. A daganatos betegségben szenvedőknél 1999-ben 12577 betegnél összesen 21026 esetben történt sugárkezelés, míg 2019-ben 19 445 betegnél 61653 esetben. Ez a terápiás módszer is növeli egyes daganatos betegek túlélési esélyeit.

A művesekezelések száma is jelentősen emelkedett. 1999-ben 7094 pácienst kezeltek 567979 esetben, 2019-ban 18553 beteget 1,25 millió esetben. Különösen nagy ütemben (évente 7,5\%-kal) nőtt a dializált betegek száma 2003-2009. között ${ }^{14}$. A veseátültetések száma a 1999. évi 257 betegről 754 betegre nőtt 2019-re. A nem daganatos vesebetegség miatti halálozás 20052014. között csökkent hazánkban¹5. Többek között ezek együttes eredménye lehet a lényegesen megemelkedett vesebetegséggel élők száma hazánkban.

A szemsebészet teljesítőképessége is jelentősen javult: 1999-ben 33341 betegen 39152 mútétet végeztek, míg 2019-ben 68633 betegen 92 308-at. Ezek a mútétek csökkentik az idősebb gyengénlátók számát.

A vakok és gyengénlátók számának csökkenése mögött lehet a koraszülöttek megfelelő ellátása is. A vakok száma kevesebb a gyermekek körében is ${ }^{16}$.

\section{Gyógyszerforgalom}

A gyógyszerfogyasztást közvetetten a vényforgalomból ismerhetjük meg. Az adatok sokat mondanak akkor is, ha figyelembe vesszük, hogy krónikus betegségek esetén gyakran előfordul, hogy egy vényen háromhavi gyógyszer mennyiség is szerepel. A gyógyszercsoportokat ATC kóddal jelöltük, zárójelben.

A daganatok esetén használt daganatellenes (LO1), immunstimuláló (LO3) illetve immunszupresszor (LO4) hatású szerekből 2009-ben 289748 vényt váltottak ki, 2019-ben 430 057-et.

A vér - és vérképző szervi betegségeknél használt antithrombotikus szerekből (BO1) és antifibrinolytikumokból (B02A) együttesen 2009-ben 7,3 millió, 2019ben már 9,8 millió vényt váltottak ki. (Eközben a betegek száma 150 000-rel nőtt.)

Az antidiabetikus terápia (A10) 2009-ben 6,1 millió vénykiváltással járt, 2019-ben pedig 7,7 millióval.

A szívre ható szerek (CO1) közül 2009-ben 5,9 millió vényt, míg 2019-ben 3,68 millió vényt váltottak ki. A béta-receptor blokkolók (CO7) vényforgalma 2009-ben 8,65 millió volt, 2019-ben 10,45 millió.

A magas vérnyomás miatt (CO2) kiváltott vények száma a 2009. évi 2,8 millióról 3,5 millióra nőtt. A lipidszintet módosító anyagokból (C10) 7,8 millióról 8,2 millióra nőtt a vények száma.
Az obstruktív légúti betegségekre ható szerekből (R03) 2009-ben 4,4 millió vényt, míg 2019-ben 4,7 millió vényt váltottak ki.

A legnagyobb vényszámot a központi idegrendszerre (N) ható szerek esetén látunk, 1999-ben 15,8 millió, 2019-ben 14,4 millió. (Az OSAP 1021-ben szereplő idegrendszert érintő betegségek száma nem indokolja ezt a nagy mennyiségü gyógyszert. A jövőre nézve érdemes áttekinteni a háziorvosok által OSAP 1021-ben jelentendő betegségeket ebben a BNO csoportban is hiszen a gyógyszerfogyasztási adatok mögött nagyszámú, tehát népegészségügyi szempontból jelentőséggel bíró betegségek állnak.)

A szemészeti készítményekre (SO1) kiváltott vények száma: 2009. évben 2,4 millió, 2019. évben 2 millió volt. A gyógyszertámogatás mértéke folyamatosan nő, csak az elmúlt 6 évben 100 milliárd Ft-tal emelkedett ${ }^{17}$.

\section{Idősödés}

Az idősödés is hozzájárul a krónikus betegségek számának növekedéséhez. Míg 1990-ben 13\%, addig 2017 ben már 19\% volt a 65 éven felüliek aránya hazánkban ${ }^{18}$. A kor elörehaladtával nő a betegségek száma, ez szinte minden általunk vizsgált betegségnél látható.

Az idősödés tehát részben eredménye az egészségügyi ellátásnak: az időben történő szűrésnek, egészségügyi beavatkozásnak, gyógyszeres kezelésnek. Csak az idősödéssel azonban nem magyarázható a betegségek számának növekedése. Látható, hogy a középkorosztályban is - mely lényegesen nagyobb számú, mint az idősek - jelentősen és egyenletesen emelkedett a vizsgált időszakban több betegségnél is az 1000 före számított betegségszám.

\section{Környezeti tényezök}

Az okok között, melyek betegségtöbbletet eredményeztek az elmúlt 21 év alatt, a környezeti tényezőket is számításba kell venni. Az élelmiszerkínálat növekedése, a magasabb jövedelmek nagyobb mennyiségú élelmiszerfogyasztást eredményeztek már az 1970-as évektől egészen napjainkig 19,20,27. Ezzel párhuzamosan a kényelmi szolgáltatások elterjedésével csökkent a nehéz és közepesen nehéz fizikai munkavégzés. Az informatikai eszközök az ülőmunkán kívül kihatnak a fizikai szempontból passzív szabadidő eltöltésre is. Nagyrészt ezek eredménye a lakosság tömeges elhízása.

Az OTÁP vizsgálatok alapján, országos reprezentatív mintából számított adatok szerint 2009-ben az elhízott és túlsúlyos férfiak aránya 65\%, a nőké 61\%, míg 2014ben a férfiaké $65 \%$, a nőké $60 \%$ volt 22,23 . 
Az elhízás és az azzal összefüggő betegségekkel kapcsolatban a 2009. évi OLEF adatai alapján két viszonylatban végeztünk számításokat²4. Vizsgáltuk a túlsúlyosok és a normál vagy sovány testalkatúak, illetve, az elhízottak és a normál vagy sovány testalkatúak közötti megbetegedési arányokat. A magas vérnyomás, magas koleszterinszint, szív- és érrendszeri betegségek, ízületi fájdalom, cukorbetegség már a túlsúlyosoknál is szignifikánsan magasabb volt a normál, illetve sovány testalkatúakhoz képest. Az elhízottak vs. normál vagy sovány testalkatúak esetén az értékek mind magasabbak voltak, és a betegségek sora bővült a nyaki-, derék és hátfájdalommal is. Legnagyobb esélyhányadost a cukorbetegségnél mértünk, az elhízottak a normál testsúlyúakhoz képest négyszer nagyobb eséllyel lesznek cukorbetegek. (Konfidencia intervallum 95\%os valószínúségi tartományban: 3,06-5,22) De a túlsúly és a normál vagy sovány testalkat viszonylatában is 2,39 volt az esélyhányados (konfidencia intervallum: 1,82-3,139). A magas vérnyomás esélyhányadosa az elhízottak vs. normál vagy sovány testalkat esetén 2,918 (konfidencia intervallum: 2,57-3,45), míg a túlsúlyosok és normál vagy sovány viszonylatában 1,77 (konfidencia intervallum: 1,54-2,04).

A cerebrovasculáris betegségek növekvő számát is írhatjuk részben az elhízás, illetve az annak következtében kialakuló magas vérnyomás kontójára. A cerebrovasculáris betegségek miatti halálozás csökkent, a túlélők száma nőtt ${ }^{25,26}$. A háziorvosi jelentés szerint számuk meghaladja a 600 000-et.

Az elhízással mutat összefüggést több daganatos betegség is a felnőtteknél. Például: mellrák, vastagbéIrák, hasnyálmirigyrák, májrák, epehólyagrák, méhrák, petefészekrák ${ }^{27}$

De a daganatok kialakulásában számos más biológiai tényező is kockázati tényezőként vehető figyelembe, például vírusok (hepatitis B-, C-vírus, HPV) és a mikroszkopikus gombák (fumonizin, aflatoxin) ${ }^{28}$.

Daganatkeltő hatással rendelkeznek egyéb fizikai tényezők is (UV-A és B sugárzás): A rákkeltő vegyi anyagok közül pedig számos napjainkban is forgalomban van (benzol, króm VI) vagy hulladék formájában fejti ki hatását (pl.: azbeszt) ${ }^{29}$. A rákkeltők felhasználásának korlátozása, és a technikai határértékek csak részben vagy látszólag jelentenek védelmet az ember szempontjából, hiszen a rákkeltő anyag már minimális szinten is elindíthatja a kóros folyamatot.
Bizonyítottan rákkeltő a dohányfüst, mely a dohányzás köztéri és munkahelyi korlátozása ellenére még mindig nagyon sok háztartásban előfordul30.

Több allergiás betegség kialakulásához is hozzájárulnak környezeti elemek. Az allergiás légúti betegségek kialakulásának kockázatát nagymértékben növelik a biológiai tényezők (pollen, penész, állati szőrök, poratka), de kiválthatják vegyi anyagok is, többek között fémek, illatanyagok is 31,32 .

Az élelmiszer-allergiás megbetegedések növekedésében az allergén tartalmú élelmiszereken túl33, nagy valószínúséggel szerepe van az élelmiszerekben lévő adalékanyagoknak. Az emulgeáló anyagoknak, melyek megváltoztatják a bél áteresztő képességét, valamint mikrobiom összetételét is, és nagy valószínűséggel a diabetes és a nem fertőző bélgyulladások kialakulásában is szerepük van ${ }^{34}$.

A felsorolt okok, az elemzés átfogó jellegénél fogva, csak kis részben vagy általánosságban érintik egy-egy betegség etiológiai hátterét, hiszen minden betegség mögött tudósok sora végez különböző irányú kutatásokat. Az OSAP 1021 eredményeinek ismertetésével mindössze annyi volt a célunk, hogy bemutassuk: az elmúlt 21 évben, a viszonylagos anyagi jólét keretei között jelentős számban és mértékben megnőtt a gondozást igénylő megbetegedések száma. Ezek nagy része primer prevencióval megelőzhető lenne. A vizsgálattal szeretnénk rámutatni arra, hogy a jelenlegi prevenciós módszerek, ha egyáltalán léteznek, nem vagy nem eléggé hatékonyak. Az egészségügyi ellátás kapacitása személyi és anyagi vonatkozásban is véges, tehát a gyógyítási eszközök és módszerek fejlesztésén túl a megelőzés terén is a bizonyítottan hatékony módszerekre kellene fókuszálni a jövőben.

Az OSAP 1021 adatgyújtés kiegészítése nagyban emelné az értékét. Így például a páciensek testtömeg indexe kétévente képet adna az elhízás mértékéről. A dohányzási szokások adataiból prognosztizálni lehetne a tüdőrák alakulását. Célszerü lenne a daganatos betegségeket és az allergiás megbetegedéseket tovább specifikálni. Szükség lenne az 1-es és 2-es típusú diabetes, valamint a pajzsmirigy hypo-és hiperfunkció elkülönített gyűjtésére. Érdemes lenne az elektronikus adatgyűjtés lehetőségeivel élve a rizikótényezőket (kiemelten az elhízás) összekapcsolni a megbetegedésekkel. A háziorvosi jelentésekből képet alkothatnánk az átszűrtségi adatokról is. 


\section{Anyagi támogatás}

A tanulmány az EFOP-1.9.6-16 Elektronikus egészségügyi ágazati fejlesztések 2014-2020. C komponens keretében készült.

\section{Szerzök hozzájárulása}

B.M.: kézirat elkészítése; K.Zs.: statisztikai elemzés; M.B.: adatszerzés; K.L.: adatszolgáltatás

\section{Érdekeltségek}

A szerzőknek nincsenek a tartalmat érintő érdekeltségeik.

\section{Nyilatkozatok}

A szerzők nyilatkoznak arról, hogy a cikk végleges változatát valamennyi szerző elolvasta és jóváhagyta.

\section{Irodalomjegyzék}

1. https://ec.europa.eu/eurostat/databrowser/view/ hlth_cd_asdr2/default/table?lang=en

2. https://www.ksh.hu/elef2019

3. http://hmap.unideb.hu/bemutatkozas.php

4. https://www.imeonline.hu/article.php?article=2008._VII./8/haziorvosi_teteles_betegforgalmi_ jelentesek_elemzese_2007_junius_2008_majus

5. https://www.ksh.hu/interaktiv/terkepek/mo/ egeszseg.html

6. 288/2009.(XII.15.9 Korm. rendelet az Országos Statisztikai adatgyújtési program adatgyújtéseiről és adatátvételéről

7. https://www.ksh.hu/egeszsegugy-baleset

8. Gresz M. Az emlő rosszindulatú daganata és az emlőszürés viszonya Magyarországon az Országos Egészségbiztosítási Pénztár adatainak tükrében. Orvosi Hetilap 2012 (153. évf.) 44. sz. 1745-1751. https://doi.org/10.1556/OH.2012.29427

9. https://www.ksh.hu/docs/hun/xstadat/xstadat eves/i_wnh001.html

10. https://www.europarl.europa.eu/news/hu/headlines/priorities/az-eu-es-az-egeszsegugy/20200131STO71517/rakellenes-vilagnap-igy-kuzd-az-eu-a-betegseg-ellen

11. https://www.europarl.europa.eu/news/hu/headlines/society/20171023ST086602/rakkelto-anya- gok-jobban-vedene-a-karos-hatasuknak-kitett-munkavallalokat-az-ep

12. I Kostoglou-Athanassiou, K. Ntalles. Hypothiroidism -new aspects of an old diseases. Hippokratia 2010. Apr-June 14(2) .pp.: 82-87. https://www.ncbi. nlm.nih.gov/pmc/articles/PMC2895287/

13. Tóth $G$, Bán $A$, Vitrai J, és mtsai. Az egészségügyi ellátáshoz való hozzáférés szerepe az egészségegyenlőtlenségekben - A szívizominfarktus-megbetegedések és halálozások területi különbségei. https://doi.org/10.24365/ef.v58i3.173

14. Kulcsár I, Illés M, Kovács L. Dialíziskezelés Magyarországon 2010-2015. Hypertonia és Nephrológia 2016.; 20(05). https://elitmed.hu/kiadvanyaink/hypertonia-es-nephrologia/dializiskezeles-magyarorszagon-2010-2015

15. Paksy A, Kiss I. A vese nem daganatos megbetegedései miatti halálozás jellemzői Magyarországon 2005-2014. között. Lege Artis Medicinae 2017;27(01-02). HTTPS://ELITMED.HU/ KIADVANYAINK/LEGE-ARTIS-EDICINAE/A-VESE-NEM-DAGANATOS-BETEGSEGEI-MIATTI-HALALOZAS-JELLEMZOI-MAGYARORSZAGON-2005-2014-KOZOTT

16. Maka E, Imre L, Somogyvári Zs et al. Koraszülöttek ideghártya-elváltozása miatti kezelés neonatalis intenzív centrumokban. Orvosi hetilap 2015, 156. évf. 5. sz. pp.: 192-196. https://doi.org/10. 1556/ OH. 2015.30090

17. https://hgysz.hu/blog/a-2020-evi-kozponti-koltsegvetes-gyogyszereszetet-erinto-legfontosabb-szamai/

18. Monostori J, Gresits G. Idősödés. in: Monostrori J, Öri P, Spéder Zs. (szerk): Demográfiai portré 2018. KSH NKI, Budapest, 127-145.

19. http://www.ksh.hu/docs/hun/xftp/idoszaki/elmerl/ elmerl01.pdf

20. http://www.ksh.hu/docs/hun/xftp/stattukor/elelmfogy/elelmfogy08.pdf

21. https://elir.aki.gov.hu/cikk/egy-fore-juto-elelmiszerfogyasztas

22. https://www.ogyei.gov.hu/otap_2009/

23. https://ogyei.gov.hu/dynamic/OTAP2O14_OH\%2O cikk\%20l.pdf

24. Bényi M, Kéki Zs, Hangay I et. al. Elhízással öszszefüggő morbiditásnövekedés az Országos Lakossági Egészségfelmérés alapján (2009). Orvosi Hetilap, 2012 (153. évf.) 20. sz. 768-775. https://doi. org/10.1556/oh.2012.29302

25. https://semmelweis.hu/hirek/files/2019/10/Stro- 
ke-r\%C3\%B31-\%C3\%A7ltal\%C3\%A7ban-2019.10.14-3. pdf

26. http://old.semmelweis.hu/wp-content/phd/phd_ live/vedes/export/ovarycsaba.d.pdf

27. http://medicalonline.hu/kitekinto/cikk/brit_orvosi_szovetseg_mar_az_elhizas_a_rak_fo_oka

28. https://www.webbeteg.hu/cikkek/egeszseges/4752/az-elelmiszerek-es-a-mikotoxinok

29. https://www.webbeteg.hu/rakkelto-anyagok

30. http://daganatok.hu/a-dohanyzas-es-a-rak/a-paszsziv-dohanyzas-hatasai
31. https://www.dorkaszappan.hu/bor-irritaciot-okozo-kozmetikumok

32. Ábrahám $\mathrm{E}$, Reibl $\mathrm{D}$, Bényi $\mathrm{M}$ et al. Kéztisztító és kézfertőtlenítő szerek lehetséges mellékhatása. Egészségtudomány 2020;64(4): 81-99. https://doi. org/10.29179/EgTud.2020.4.81-99

33. http://enaplo.com/Documents/allergen_osszetevok.pdf

34. http://medicalonline.hu/tudomany/cikk/ujabb_ellenseg_az_emulgealoszerek 